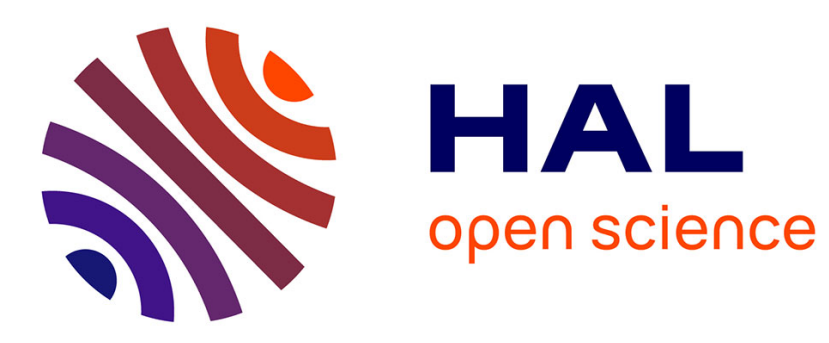

\title{
Modelling the mechanical strength development of treated fine sediments: a statistical approach
}

Ishak Moghrabi, Harifidy Ranaivomanana, Fateh Bendahmane, Ouali Amiri, Daniel Levacher

\section{- To cite this version:}

Ishak Moghrabi, Harifidy Ranaivomanana, Fateh Bendahmane, Ouali Amiri, Daniel Levacher. Modelling the mechanical strength development of treated fine sediments: a statistical approach. Environmental Technology, 2018, pp.1-20. 10.1080/09593330.2018.1432697 . hal-01983092

\section{HAL Id: hal-01983092}

\section{https://hal-normandie-univ.archives-ouvertes.fr/hal-01983092}

Submitted on 12 Mar 2019

HAL is a multi-disciplinary open access archive for the deposit and dissemination of scientific research documents, whether they are published or not. The documents may come from teaching and research institutions in France or abroad, or from public or private research centers.
L'archive ouverte pluridisciplinaire HAL, est destinée au dépôt et à la diffusion de documents scientifiques de niveau recherche, publiés ou non, émanant des établissements d'enseignement et de recherche français ou étrangers, des laboratoires publics ou privés. 


\section{Funding}

This work is financially supported by the French ministry of education.

\section{N.B: All figures can be reproduced in black and white colors.}

\section{Modelling the mechanical strength development of treated fine sediments: A}

\section{statistical approach}

Ishak Moghrabi, Harifidy Ranaivomanana, Fateh Bendahmane, Ouali Amiri, Daniel Levacher

Sediments valorisation (recycling) has revealed limitations due to different restrains and practical difficulties. When it comes to different recovery methods, the possibility of valuing diverse types of sediments still needs to be defined. Using a statistical approach, the present study aims to quantitatively estimate the mechanical resistance of stabilized sediments. A data base that included twenty-two fine sediments is selected and assembled from literature. These sediments were treated with distinct types and quantities of additives (fillers and/or binders). The present study includes two parts. On one hand, using multivariate linear regression tool of XLstat software, an analytical model that highlights effects of various parameters influencing the mechanical resistance of treated sediments after 28 days, is obtained. This model showed that organic matter content and plasticity index are the most significant factors of sediments characteristics, while cement is the best mechanical strength booster. On the other hand, evolution of treated sediments mechanical resistance over time is modelled by an exponential relationship using a least square regression method. Both models showed acceptable accuracies compared to a panel of selected experimental values.

Keywords: Dredged sediments, mass stabilisation, unconfined compressive strength, statistical approach, multivariate linear regression

\section{Introduction}

Dredging operations of sediments are necessary to maintain harbours and waterways navigability as well as to maintain energy production from hydropower plants in dams. In France, 24.69 million tons of dry matters of sediments were dredged in 2011 [1]. Due to limiting environmental regulations, the deposits of dredged sediments are strictly controlled, and managing these materials 
became an environmental concern. Recovery of dredged sediments is an alternative to its disposal at sea and to on-land storage. Moreover, due to the contamination of sediments, their valorisation (recycling) became an environmental and social constraint [2-4].

The complexity issue of ashore sustainable management of sediments is explained by the fact that several combined aspects must be considered i.e. regulatory (legislations), scientific (characterization, valorisation), technical (implementation), socio-economic (cost of operations, acceptability of sediment based products). Partial solutions were suggested mostly for contaminated sediments. Relevant studies are based on multi-criteria analysis methods; common criteria are first concerned with the environment, and sometimes also with economic and/or social aspects [5-13]. However, practical and technical considerations still need to be evaluated.

Many studies have been put forward concerning the valorisation of dredged sediments since 1970. Rozière et al. [14] used 7.9 dwt\% (percentage from total dry mass) of pre-treated sediments (thermo-chemical treatment) as filler in self-consolidating concrete. Aouad et al. [15] incorporated $25.74 \mathrm{dwt} \%$ of sediments to be introduced into the kiln for Portland cement clinker production. After a thermo-chemical pre-treatment, Lafhaj et al. [16] produced clay bricks substituting clay by pretreated sediments (from 25 to $45 \mathrm{dwt} \%$ ). Zdiri et al. [17] substituted 12 to $14.6 \mathrm{dwt} \%$ of ordinary limestone aggregates by marine and fluvial sediments to produce roller compacted concrete (RCC). Results showed that the use of sediments in RCC improved its workability and reduced hydration heat.

In valorisation of sediments, the main concern is to recover considerable volume of sediments, with least treatment cost. Chemical and thermal pre-treatments at laboratory scale may not be applicable in full-scale due to technical and cost limitations, and due to environmental concerns ( $\mathrm{CO}_{2}$ emission). Mass stabilization involves sediments as main constituent in mixtures. In such recovery method, treated materials can be used for dyke construction [18], fill material [19] or road sub-grade construction [20]. It requires a process of solidification-stabilization (S/S), a wellknown treatment approach of fine grained soils by cement and lime admixtures [21-24]. However, sediments recovery methods such as: substitution in concrete, bricks and ceramic materials fabrication do not allow to use significant quantity of sediments. Furthermore, there is no interest in treating sandy sediments, which can be directly reused for beach nourishment without any treatment expenses. Consequently, mass stabilization of raw fine sediments without any chemical or thermal pre-treatment, is the most reasonable and attractive solution for sediments valorisation.

Anger [21] developed a tool to preselect the most appropriate recovery method for fine sediments i.e. cement industry, concrete manufacturing, road engineering, ceramics industry and agricultural 
use. This tool qualitatively predicts the compatibility of sediments to be recycled in the beforementioned recovery methods, to select the most convenient afterwards. Nevertheless, there is a need for a quantitative understanding of the treatment process. In case of sediments mass stabilisation, a quantitative approach i.e. analytical, statistical or empirical is needed, that allows to estimate the mechanical resistance of treated sediments.

Based on a statistical calculation, the suggested approach permits to estimate the mechanical resistance of treated sediments considering the properties of raw sediments and applied treatment (type and quantity). Unconfined compressive strength (UCS) is the most commonly used parameter to evaluate the mechanical resistance of construction and road materials. To use an alternative material for road sub-grade layer construction, depending on traffic intensity, UCS of 1 MPa to 1.5 MPa is required [22]. However, UCS of 100 to $300 \mathrm{kPa}$ is sufficient for fill materials [19,23]. Therefore, UCS of treated sediments is chosen as a criterion in the present study. From literature and available reported studies, UCS at 28 days $\left(\mathrm{UCS}_{28}\right)$ is a recurrent proposed parameter. Moreover, cementitious materials reach approximately the maximum resistance at 28 days. Thus, $\mathrm{UCS}_{28}$ is undertaken to model the mechanical resistance of treated sediments as function of sediment's characteristics and applied treatment. After identifying the main effective parameters, $\mathrm{UCS}_{28}$ is modelled using multivariate linear regression tool of XLstat software. Furthermore, LCPC-SETRA [22] prescribed to assess time needed to develop necessary mechanical resistance of treated materials. Subsequently, UCS development of treated sediments is modelled versus time using a least square method.

\section{Input data}

In case of road and related materials recovery method, according to the tool described by Anger [21], three physical properties were pointed out to influence treated sediment's UCS mechanical performance. These were sediment organic matter content (OM), plasticity index (PI) and $\mathrm{D}_{50}$ i.e. grain's median diameter. In the present study, the physical properties of raw sediments, types and quantities of used additives, quantity of water in mixtures, all have been considered.

The expected quantitative formula helps to reach three goals:

(1) A better understanding of raw sediment's properties effects over UCS,

(2) A better understanding of treatment effectiveness,

(3) Based on predicted mechanical resistance, a selection and/or orientation of sediments into the most convenient recovery method can be conducted, according to required UCS.

Before running through the statistical analysis, it is necessary to expand the effect of each parameter over the physical and geotechnical properties of treated sediments. A literature review has 
allowed a better understanding of positive or negative effects of these parameters over mechanical resistance of treated sediments.

\subsection{Physical properties of raw sediments}

\subsubsection{Grain size distribution}

Sediment is a complex matrix made up of inorganic matters, anthropic composites and water. Usually, sediments are described by their structure and mineralogical composition. The grain size distribution (GSD) provides necessary parameters used for soil classification.

\subsubsection{Organic matter content}

Origin of organic matter (OM) in sediments varies widely. It can contain vegetal debris, humic colloids, and microorganisms. The organic fraction interacts with the mineral clayey particles providing a clayey-organic complex of various chemical stability levels [24]. This interaction, modifies soil characteristics such as the plasticity and the consolidation behaviour [25], and prevents the agglomeration of clay particles after the addition of cement [26]. When organic matter content increases from 0 to $4 \%$, the void index increases and consequently the compressibility of a factor 10 [27]. OM has low density with respect to mineral fraction, thus OM leads to decrease the density of sediments, consequently increasing the optimal water content by compaction [28]. Organic matter can retain up to 20 times of its self-weight in water as reported by [29]. Le Guern et al. [30] reported that, as OM content increases, UCS of treated sediments decreases.

\subsubsection{Atterberg limits}

It is well known that fine soil is sensible to water. The Atterberg limits i.e. plastic limit PL, liquid limit LL and plasticity index PI are indicators of soil plasticity and allow investigating its behaviour under hydric variations. The values of PL, LL and PI depend on proportion and activity of clay in soil. PI defines the interval of water content in which soil remains flexible and deformable while maintaining certain shear resistance [21].

\subsubsection{Methylene blue value}

Clay minerals found in the sediments are mainly depending on the physical and chemical weathering of rocks. The laminated crystalline structure of clays gives them a set of behaviour properties called activity i.e. swelling phenomena, plasticity, cohesion, water affinity,... [31]. 
Methylene blue value (MBV) corresponds to the quantity of blue methylene absorbed on the external and internal surfaces of the clay particles contained in sediments. The adsorption of significant amount of methylene blue indicates the presence of swelling clay in sediments.

Both tests, Atterberg limits and Methylene blue value MBV, help to evaluate the sensibility of soil to water. However, in case of medium to high clayey soils, MBV becomes less sensitive while plasticity index more sensitive. Beixing et al. [32] studied the effect of clay content of manufactured sand on concrete performance, where MBV is used to quantify clay activity in blended concrete mixtures. They reported that MBV is affected by clay content present in aggregates and its liquid limit. The increase of MBV decreased compressive resistance, workability and flexural strength as well it promoted shrinkage of concrete. Therefore, to estimate the effect of sediments substitution in concrete, one should consider MBV value. Nevertheless, knowing PI is very useful for earthworks designing (fills, banks, dykes, roads...) [21], then Atterberg limits should be considered to assess soil water sensitivity in case of sediments treatment or mass stabilisation.

\subsubsection{Water content in tested mixture}

Sediments are dredged with very high initial water content, from 100 to $300 \mathrm{dwt} \%$ even more, depending on dredging method and sediment's mineralogy. This high initial water content is an important brake on the application of most recovery methods. From a technical and economic point of view, in the best-case scenario, sediments are treated at its initial water content. However, the mechanical strength of treated materials is inversely proportional to the water/cement content [33]. Consequently higher water content requires higher quantity of binders to solidify the sediments [34], and therefore more expensive treatment.

\subsection{Additives}

\subsubsection{Cement}

Cement is the worldwide well known binder for fine soil treatment [35-38]. The dissolution of cement increases the concentration of $\mathrm{Ca}^{2+}$ ions, which reduces the hydrophilic property of organic molecules [39]. Rekik et al. [26] treated marine sediments at the initial water content (120 \%) using 2-15\% of cement with respect to dry weight of sediments. They reported that calcium silicate hydrates are formed around clay-organic aggregates, producing larger clusters, which accelerates the primary consolidation process and reduces the secondary compression. Wang et al. [40] observed 
that the addition of 3 to $6 \%$ of cement or lime, increased liquid and plastic limits of marine sediments. And obviously, increasing cement dosage increases the mechanical resistance of treated sediments [26,39,41,42].

\subsubsection{Lime}

Humic acid in the soil influence the setting of cement, so it is necessary to add lime to cement in the stabilization/solidification treatment process [41]. Four types of reactions can take place during stabilization with lime: (i) cationic exchange [43,44], (ii) flocculation and particle aggregation [43], (iii) lime carbonation [45], and (iv) pozzolanic reactions at long term between lime, silica and alumina.

The reaction of lime with water produces calcium hydroxide with high emission of heat according to equation 1 given below:

$$
\mathrm{CaO}+\mathrm{H}_{2} \mathrm{O} \rightarrow \mathrm{Ca}(\mathrm{OH})_{2}+1155 \mathrm{~kJ} / \mathrm{kgCaO}
$$

Using lime fixation method, the quantity of lime to reach high constant $\mathrm{pH}$ can be adjusted. Banoune et al. [46] treated two river sediments using lime from 2-15 wt\%. They observed that increasing the quantity of lime increases the mechanical resistance and optimal water content $\mathrm{W}_{\mathrm{SPO}}$ (Standard Proctor Optimum) but decreases optimal dry density $y_{\mathrm{SPO}}$ and plasticity index.

\subsubsection{Fly ash}

According to the American Concrete Institute (ACI), fly ash is defined as the finely divided residue resulting from the combustion of ground or powdered coal [47]. Fly ash develops pozzolanic properties, in presence of moisture and lime or cement. It chemically reacts with calcium hydroxide at ambient temperature to form compounds having hydraulic properties [41]. Fly ash is classified into two classes i.e. $C$ or $F$ according to their chemical composition [48]. Class $F$ fly ash is pozzolanic in nature, contains less than $10 \%$ of $\mathrm{CaO}$, and needs a cementation agent. While class $\mathrm{C}$ fly ash contains more than $20 \% \mathrm{CaO}$, and doesn't need a cementation agent.

Silitonga [49] investigated the effect of two types of fly ash with different percentages (4-8 dwt\%) combined with $2 \mathrm{dwt} \%$ of lime and $3 \mathrm{dwt} \%$ of cement on marine sediments. Results demonstrated that sediments treated with class $\mathrm{F}$, containing higher percentage of $\mathrm{SiO}_{2}$ and $\mathrm{Al}_{2} \mathrm{O}_{3}$, showed higher mechanical resistance than class $\mathrm{C}$ fly ash.

\subsubsection{Silica fume}


Silica fume or micro-silica is a by-product made from the silicon and its alloys production. In 1994, McKennon et al. [50] found that the addition of silica fume on soil treated with lime or Portland cements promotes the creation of calcium silicate hydrate and control the creation of unsuited products such as Ettringite. Kalkan [51] reported that the treatment of clayey soils with silica fume decreases the rate of swelling and desiccation cracks. Silitonga [49] has also studied the effect of different additives on fine sediment's mechanical resistance. He observed that the addition of silica fume improves the unconfined compressive strength at both short and long terms.

\subsubsection{Sand}

Sand is added to dredged sediments as a granular corrector, it improves sediments granular structure and subsequently reduces its porosity. It brings a dilution effect by modifying natural parameters, where the addition of dry sand decreases clay and OM contents, and accelerates natural dewatering that facilitates the implementation of the treated sediments [52].

Table 1 shows the considered input parameters in the present statistical analysis. Additives were expressed by mass percentage of raw dry sediments. However, water content is referred by percentage of total dry mass (dwt \%).

\section{Method}

Within the frame of the present study, a total of 22 different fine sediments (fluvial, marine and dams), treated with various quantities of additives i.e. cement, lime, sand, fly ash and silica fume, compacted in cylindrical moulds with height/diameter ratio of 2, constituted the database. This database is issued from 7 references [21,42,46,49,53-55] (see Table 4 in Annex).

The multivariate linear regression is an approach to model a relationship between a scalar dependent variable and one or more explanatory variables. The objective is to estimate $\mathrm{UCS}_{28}$ through a linear combination written as follows:

$$
U C S=C_{1} V_{1}+C_{2} V_{2}+\ldots+C_{i} V_{i}+\ldots+C_{n} V_{n}+e
$$

(2)

Assuming there are n parameters, $C_{i}$ is the coefficient corresponding to parameter $i, V_{i}$ is the value taken by parameter $i$, and $e$ is a disturbance term. Three steps are required to conduct this regression, as shown in Figure 1. 


\subsection{Database acquisition}

Input parameters were identified in section 2 i.e. sediment's properties, water content in mixtures, type and quantity of binders/additives. Thereafter, 133 tested mixtures results were acquired from the beforementioned references. Each test constituted of input parameters and its corresponding compressive strength $\mathrm{UCS}_{28}$.

\subsection{Elimination of correlated parameters}

Before performing regression analysis, linearly correlated parameters must be eliminated from input data using a data-mining tool called principal component analysis (PCA). When several parameters are correlated, one parameter should be retained. PCA is a projection method of observations from p-dimensional space ( $\mathrm{p}$ variables) to a k-dimensional space (where $\mathrm{k}<\mathrm{p}$ ). It allows the full set of variables to be reduced to a subset representing the principal components assuming a linear correlation between the variables. Each parameter is represented in a factor space (axis), and the geometrical representation associates a vector to each parameter. The scalar product of two vectors is the linear correlation coefficient between them. Only parameters having high correlation should be inspected in PCA projection plans.

In these PCA projection plans, two variables follow a linear relationship when their positions are near the unit circle and very close to each other (positive correlation) or near to the unit circle and diametrically opposite (negative correlation). Two variables are independent when their representations are in a quadrature.

\subsection{Multivariate linear regression}

To obtain an equation with significant parameters, ineffective parameters should be eliminated. In regression analysis, p-value (probability value) indicates whether the relationships between independent and dependant parameters are statistically significant or not. The p-value examines the null hypothesis that a variable does not affect a dependant variable. If the p-value of a parameter is less than the conventional level of significance, 0.05 [56], the null hypothesis is rejected.

Another method to examine the significance of parameters is performed, as shown in equation 3, by investigating the influence of each parameter on predicted $\mathrm{UCS}_{28}$. For a parameter $i$ and at an observation $j$, the value taken by the parameter $\left(V_{i j}\right)$ is multiplied by its corresponding coefficient $\mathrm{C}_{\mathrm{i}}$. The obtained values were normalized by its sum among all the observations. The maximum value $\left(I_{i}\right)$ among tested mixtures is the influence of parameter $i$ on predicted $\mathrm{UCS}_{28}$. 


$$
I_{i}=\max \left(I_{i j}\right)=\max \left(\frac{C_{i} \times V_{i j}}{e+\sum_{j=1}^{p}\left|C_{i} \times V_{i j}\right|} * 100\right)
$$

$I_{\mathrm{ij}}$ : Influence of parameter $i$ on mixture $j$ on $\mathrm{UCS}_{28}$ (predicted),

$C_{i:}$ Coefficient corresponding to parameter $i$,

$V_{i j}$ : Value taken by parameter $i$ for mixture $j$,

$e$ : Disturbance term (see equation 3),

$p$ : Total number of observations.

Parameters with low influence were eliminated, maintaining high adjusted coefficient of determination (adjusted $\mathrm{R}^{2}$ ) and low root mean square error (RMSE) between predicted and experimental $\mathrm{UCS}_{28}$.

\section{Results and discussion}

First principal component analysis (PCA 1) is performed using 17 input parameters (Table 1) and 133 tested mixtures to eliminate correlated parameters. Note that the sum of variability of chosen projection factors should be high to guarantee good projection of initial multi-dimensional data. When the variability represented by the first two factor plans is not very high, complement factor plans to be added to avoid misinterpretation of results.

Table 2 shows correlated parameters, and PCA projections in Figure 2 validate correlations as follows:

- $\mathrm{D}_{10}, \mathrm{D}_{30}, \mathrm{D}_{50}, \mathrm{D}_{60}$ and $\mathrm{D}_{90}$ in Figure 2(a) and (b);

- $\quad$ LL and PL in Figure 2(a) and (c);

- OM and PLin Figure 2(a) and (c).

The median diameter $\left(D_{50}\right)$ is chosen among other diameters since it is the most representative of the particle size distribution. Figure 3 shows the graphical inspection of correlation between OM and PL; LL and PL, where the presence of trends confirms the correlation. Equations 4 and 5 show linear relationships between OM and PL; LL and PL respectively. Likewise Maherzi et al. [57] reported that OM content is correlated with PL of fine sediments. Knowing that PI is equal to LL-PL, and since plasticity index PI is not correlated with any parameter, thus PI is selected as the representative factor for sediments plasticity, that allows to keep OM and eliminate PL and LL. 


$$
\begin{gathered}
O M=0.28 \times P L-2.3 \\
L L=1.13 \times P L+16.7
\end{gathered}
$$

Adjusted coefficient of determination $\mathrm{R}^{2}$, the root mean square error (RMSE) and parameters coefficients and p-values of performed linear regressions, are given in Table 3. The first multivariate linear regression is performed using 133 observations and 10 parameters. Figure 4 shows the normalized coefficients and coefficient's sampling standard deviation of regression 1. For easier use of the model, an equation with least number of parameters must be achieved without decreasing the accuracy of the model, where better model generates higher adjusted $\mathrm{R}^{2}$ and lower RMSE.

As shown in Table 3, p-values of $\mathrm{D}_{50}, \mathrm{MBV}$ and $\mathrm{S}$, are much higher than the significance level (0.05), and therefore these parameters should be eliminated. On the other hand, knowing the significant role of lime in sediments treatment (see section 2.2.2), $\mathrm{L}$ is not eliminated even that its $\mathrm{p}$ value is higher than 0.05 . Using equation 3, three parameters are found to have low influence on predicted $\mathrm{UCS}_{28}$ : $\mathrm{D}_{50}(-4.6 \%), \mathrm{MBV}(-3.8 \%)$ and sand S (-6.9\%). The low influence of $\mathrm{D}_{50}$ can be explained by the fact that the investigated $\mathrm{D}_{50}$ range is narrow, see Table 1 , since only fine sediments were considered. The influence of MBV is negative, yet low. That can be explained by the fact that soil sensitivity to water is better characterized by PI in case of earthworks (see paragraph 2.1.1). When adding sand for sediments treatment, several authors fixed water content with respect to percentage of sediments. Thus, they neglected the decrease of water content with respect to total dry mass (dwt \%), that resulted in negative coefficient, yet low, of sand. A parametric study could help to better identify the effect of sand on sediments treatment.

In regression 2, three parameters were eliminated, namely: sand content, $\mathrm{MBV}$ and $\mathrm{D}_{50}$. This regression generated approximately same $\mathrm{R}^{2}$ and RMSE as regression 1 (Table 3 ) which ensured that the eliminated parameters did not affect model's convergence (equation 6). Figure 5 shows the normalized coefficients and sampling standard deviation of the seven considered parameters. The pvalue of $\mathrm{L}$ (0.056) is lightly higher than the significance level, then $\mathrm{L}$ is considered a significant parameter. Furthermore, p-values of other parameters are much lower, thus null hypothesis is neglected.

$$
U C S_{28}(\text { predicted }=2.05-0.02 \times P I-0.044 \times O M-0.019 \times W+0.019 \times L+0.086 \times S F+0.14 \times C+0.043 \times F A
$$

With a view to increase the accuracy of the present study, and knowing that sediments were treated with several types and classes of cement (CEM I or CEM II; 32.5MPa or 42.5MPa) and fly 
ash classes ( $\mathrm{C}$ and $\mathrm{F}$ ), the chemical composition of these additives is used instead of total quantities in the third regression.

Four oxides were chosen to replace the dosages of cement and fly ash $\left(\mathrm{SiO}_{2}, \mathrm{CaO}, \mathrm{Al}_{2} \mathrm{O}_{3}\right.$ and $\left.\mathrm{Fe}_{2} \mathrm{O}_{3}\right)$ since it constitutes more than $80 \%$ of the composition. Correlation coefficients between cement and fly ash oxides are given in Table 2, and principal component analysis (PCA 2) is given in Figure 6 where the high variability of factor plans F1-F2 is sufficient for results interpretation. Table 2 and Figure 6 show that cement $\mathrm{CaO}$ content $(\mathrm{C}-\mathrm{CaO})$ is negatively correlated with $\mathrm{C}-\mathrm{SiO}_{2}$ and $\mathrm{C}-\mathrm{Al}_{2} \mathrm{O}_{3}$. Note that $\mathrm{C}-\mathrm{Fe}_{2} \mathrm{O}_{3}$ is excluded since constant parameters should be excluded from multivariate regressions. As well, fly ash $\mathrm{CaO}$ content $(\mathrm{FA}-\mathrm{CaO})$ is negatively correlated with $\mathrm{FA}-\mathrm{Fe}_{2} \mathrm{O}_{3}$, while FA- $\mathrm{Al}_{2} \mathrm{O}_{3}$ positively correlated with $\mathrm{FA}-\mathrm{Fe}_{2} \mathrm{O}_{3}$. As a result, percentage of $\mathrm{CaO}$ used in sediments treatment, is chosen to represent cement dosage, and percentage of $\mathrm{FA}-\mathrm{CaO}$ and $\mathrm{FA}-\mathrm{SiO}_{2}$ to represent fly ash dosage.

Results of regression 3 are given in Table 3 and Figure 7, a decrease of adjusted $\mathrm{R}^{2}$ and increase of RMSE were observed. This result can be explained by the fact that one or two oxides is(are) not sufficient to neither represent fly ash nor cement. Additional parameters such as the fineness, free $\mathrm{CaO}$ in fly ash and its reactivity, could better identify the different additives, and therefore obtain better results. Except that this information was not available.

\section{Validation of model}

The model obtained from regression 2 is chosen i.e. equation 6. This model is validated using observations that were not used in the model's data set, see Table 6 in Annex. To eliminate identical handling effect of experiments originated from the same author, the validation consisted of three types of fine sediments treated with different quantities of additives and water, carried out by two authors. Figure 8 shows $\mathrm{UCS}_{28}$ (predicted) versus $\mathrm{UCS}_{28}$ (experimental) with the calculated error between them in percentage. Developed model shows $\mathrm{UCS}_{28}$ prediction with an acceptable accuracy.

\section{Evolution of UCS versus time}

It would be interesting for in situ applications, to predict short and long-term resistance of treated sediments. In this section the possibility of modelling the evolution of treated sediments UCS as a function of time UCS(t) is performed using a set of experimental data $[46,49,53]$. The acquired results represented UCS resistance of treated sediments obtained at 7, 14, 28, 60 and 90 days, see Table 7 in Annex. Equation 7 is used to model the experimental data, in a manner to fulfil the following assumptions:

- A zero-resistance imposed at $\mathrm{t}=0$ (fresh state), 
- Increasing exponential function with a calibration parameter $(\tau)$ that controls the curvature of the plot in the logarithmic scale,

- The unconfined compressive strength at 28 days is fixed such that: UCS ( $\mathrm{t}=28$ days) $=\mathrm{UCS}_{28, \exp }$, where $\mathrm{UCS}_{28, \exp }$ is the measured experimental UCS resistance at 28 days.

$$
U C S(t)=U C S_{28, \exp } \times \frac{\left(1-e^{-\frac{t}{\tau}}\right)}{\left(1-e^{-\frac{28}{\tau}}\right)}
$$

To find the optimal value of $\tau$, least square error method is used to measure the discrepancy between the experimental data and the suggested numerical model, where the sum of the square errors $\left(\mathrm{SS}^{2}\right)$ between the experimental curve and the model is an indicator of the goodness of the fit. Using 87 sets of test data, the optimal value of $\tau$ is found to be 8.88. Although $\mathrm{UCS}_{28}$ is estimated from the statistical model (equation 6), which gives equation 8:

$$
\text { UCS }(t)=f(I P, O M, L, S F, C, F A, W) \times g(t)
$$

(8)

where, $f(P I, O M, L, S F, C, F A, W)$ shown in equation 6 , and

$$
g(t)=\frac{1-e^{-\frac{t}{8.88}}}{1-e^{-\frac{28}{8.88}}}
$$

Analysing the ratios $\mathrm{UCS}_{60} / \mathrm{UCS}_{28}$ and $\mathrm{UCS}_{90} / \mathrm{UCS}_{28}$, issued from experimental values, permits to interpret UCS deyelopment with time of tested mixtures (Table 7 in Annex). Three types of UCS evolution trends were observed among acquired data set due to different applied treatments. These were plotted in Figure 9, where each type is represented by a tested mixture, fitted using model defined in equation 7 :

- Case (1): $\mathrm{UCS}_{60} / \mathrm{UCS}_{28}$ and $\mathrm{UCS}_{90} / \mathrm{UCS}_{28}$ tend to 1 , which indicates that UCS does not evolve after 28 days and $\mathrm{UCS}_{28}$ is the maximum resistance. This mechanical behavior can be linked to treatment with lime and cement. 
- Case (2): $\mathrm{UCS}_{60} / \mathrm{UCS}_{28}$ and $\mathrm{UCS}_{90} / \mathrm{UCS}_{28}$ higher than 1, which indicates that UCS continue to increase after 28 days even after 90 days [49]. This result mainly occurred with the addition of silica fume or fly ash that develops a pozzolanic activity.

- Case (3): $\mathrm{UCS}_{60} / \mathrm{UCS}_{28}$ less than 1, which indicates a drop of UCS after 28 days, this kind of result must be due to high organic matter content (Mix $N^{\circ}$ 130-131-132-133). Further interpretations are needed especially at the level of the microstructure to understand the source of this outcome.

\section{Conclusion}

Valorisation (recycling) of sediments has shown some limitations and difficulties coming from scientific, socio-economic, regulatory and technical considerations. From a geotechnical point of view, fine dredged sediments are regarded as compressible or soft soils.

In the present study, a quantitative evaluation of treated sediment's mechanical resistance is given. Organic matter content and liquid limit of fine sediments were found to be correlated with plastic limit. A statistical model is developed to estimate the mechanical resistance of treated sediments as a function of physical properties of raw sediments, type and quantity of additives. Plasticity index and OM content were identified as the most significant factors among the physical properties of raw sediments. The present study confirmed that cement imposes the best curing effect, whereas silica fume and lime showed lower effect. As reported by several authors, higher water content requires more additives to solidify/stabilize sediments, which is confirmed by the high negative coefficient of water content (W). The obtained model is validated using three different sediments with different treatments, this model ensured UCS prediction with acceptable accuracy. Nevertheless, further studies could improve accuracy by considering other parameters such as salinity of sediments, specific area of the sediment's grains, mineralogy and quantity of calcium carbonates, that was not possible herein due to data limitations.

As well, empirical modelling of the mechanical strength development as function of curing time is studied herein. The obtained exponential model showed varied accuracies depending on implemented treatments. Three types of resistance development were identified. Sediments treated with hydraulic binders showed maximum resistance approximately at 28 days, while the addition of silica fume or fly ash extended this period for 90 days or even more due to pozzolanic activity. Further studies are also needed to analyse and consider the resistance drop found in some cases, whereas it could be investigated using experiments at microstructural scale.

\section{References}


[1] CETMEF. Enquête dragage 2011 - Synthèse des donées [Dredging survey 2011 - Data synthesis]. Cerema; 2011. p. 39.

[2] JORF. Décret n 2010-369 du 13/04/10 modifiant la nomenclature des installations classées. [Decree $\mathrm{n}^{\circ}$ 2010-369 of 13/04/10 modifying the nomenclature of classified installations]. Off. J. Fr. Repub. $2010 ; 87$.

[3] MEDDE. Circulaire du 24/12/10 relative aux modalités d'application des décrets $n^{\circ}$ 2009-1341, 2010369 et 2010-875 modifiant la nomenclature des installations classées exerçant une activité de traitement de déchets [Circular of 24/12/10 on the application of Decrees Nos. 2009-1341, 2010-369 and 2010-875 amending the nomenclature of classified installations carrying out waste treatment activities]. Off. Bull. MEDDTL. 2011;1.

[4] OJEU. Directive 2008/98/EC of the European Parliament and of the Council on waste and repealing certain Directives. Off. J. Eur. Union. 2008;312.

[5] Alvarez-Guerra M, Canis L, Voulvoulis N, et al. Prioritization of sediment management alternatives using stochastic multicriteria acceptability analysis. Sci. Total Environ. 2010;408:4354-4367.

[6] Cura JJ, Bridges TS, McArdle ME. Comparative Risk Assessment Methods and Their Applicability to Dredged Material Management Decision-Making. Hum. Ecol, Risk Assess. Int. J. 2004;10:485-503.

[7] Driscoll SBK, Wickwire WT, Cura JJ, et al. A Comparative Screening-Level Ecological and Human Health Risk Assessment for Dredged Material Management Alternatives in New York/New Jersey Harbor. Hum. Ecol. Risk Assess. Int. J. 2002;8:603-626.

[8] Kim J, Kim SH, Hong GH, et al. Multicriteria decision analysis to assess options for managing contaminated sediments: Application to Southern Busan Harbor, South Korea. Integr. Environ. Assess. Manag. 2010;6:61-71.

[9] Lemiere B, Michel P, Jacob J, et al. L'outil d'aide à la décision GeDSeT: évaluer les impacts et bénéfices de différentes options de gestion des sédiments [GeDSeT decision support tool: assess the impacts and benefits of different sediment management options]. Recycl. Valoris. 2012;36:52-58.

[10] Oen AMP, Sparrevik M, Barton DN, et al. Sediment and society: an approach for assessing management of contaminated sediments and stakeholder involvement in Norway. J. Soils Sediments. 2010;10:202-208.

[11] Scheffler A, Roth T, Ahlf W. Sustainable decision making under uncertainty: a case study in dredged material management. Environ. Sci. Eur. 2014;26:12.

[12] SMOCS. Sustainable Management of Contaminated Sediments (SMOCS) - Guideline. 2013. p. 82.

[13] Sparrevik M, Barton DN, Oen AM, et al. Use of multicriteria involvement processes to enhance transparency and stakeholder participation at Bergen Harbor, Norway. Integr. Environ. Assess. Manag. 2011;7:414-425.

[14] Rozière E, Samara M, Loukili A, et al. Valorisation of sediments in self-consolidating concrete: Mixdesign and microstructure. Constr. Build. Mater. 2015;81:1-10.

[15] Aouad G, Laboudigue A, Gineys N, et al. Dredged sediments used as novel supply of raw material to produce Portland cement clinker. Cem. Concr. Compos. 2012;34:788-793. 
[16] Lafhaj Z, Samara M, Agostini F, et al. Polluted river sediments from the North region of France: Treatment with $\operatorname{Novosol}^{\circledR}$ process and valorization in clay bricks. Constr. Build. Mater. 2008;22:755762.

[17] Zdiri M, Abriak N-E, Ouezdou MB, et al. The use of fluvial and marine sediments in the formulation of Roller Compacted Concrete for use in pavements. Environ. Technol. 2009;30:809-815.

[18] Nederkassel JV, Zele SV, Renterghem BV, et al. The use of engineered sediments for the construction of a compartiment dike in the controlled flooding area of Vlassenbroek (BELGIUM). Proc. South Balt. Conf. Dredged Mater. Dike Constr. Rostock; 2014. p. 87-95.

[19] STABLE. Controlled Treatment of TBT-Contaminated Dredged Sediments for the Beneficial Use in Infrastructure Applications. Aurajoki - Turku, Finland; 2009. p. 165.

[20] Zentar R, Abriak N-E, Dubois V, et al. Beneficial use of dredged sediments in public works. Environ. Technol. 2009;30:841-847.

[21] Anger B. Caractérisation des sédiments fins des retenues hydroélectriques en vue d'une orientation vers des filières de valorisation matière [Characterization of fine sediments of hydroelectric reservoirs with a view to an orientation towards material recovery systems] [Dissertation]. [Caen]: University of Normandy; 2014.

[22] LCPC-SETRA. Traitement des sols à la chaux et/ou aux liants hydrauliques: application à la réalisation des remblais et des couches de forme [Treatment of soil by lime and/or hydraulic binders: application to the realization of embankments and road sub-grade layer]. Paris: LCPC, Laboratoire central des ponts et chaussées; SETRA, Service d'études techniques des routes et autoroutes; 2000. p. 246.

[23] Stabcon. Vägledning för nyttiggörande av muddermassor i hamn- och anläggningskonstruktioner [Recovery guidance of sediments in port and harbors]. [Sweden]: Swedish geotechnical institute; 2011.

[24] Stevenson FJ. Humus Chemistry; Genesis, Composition, Reactions. New York: John Wiley \& Sons; 1994.

[25] Keller GH. Organic matter and the geotechnical properties of submarine sediments. Geo-Mar. Lett. 1982;2:191-198.

[26] Rekik B, Boutouil M. Geotechnical properties of dredged marine sediments treated at high water/cement ratio. Geo-Mar. Lett. 2009;29:171-179.

[27] Rashid MA, Brown JD. Influence of marine organic compounds on the engineering properties of a remoulded sediment. Eng. Geol. 1975;9:141-154.

[28] Husein Malkawi AI, Alawneh AS, Abu-Safaqah OT. Effects of organic matter on the physical and the physicochemical properties of an illitic soil. Appl. Clay Sci. 1999;14:257-278.

[29] Pierzynski GM, Vance GF, Sims JT. Soils and Environmental Quality. Third. CRC Press; 2005.

[30] Le Guern M, Boutouil M, Saussaye L, et al. Geotechnical and mechanical characterisation of three marine dredged sediments treated with hydraulic binders. Proc. South Balt. Conf. Dredged Mater. Dike Constr. 2014. p. 13-18.

[31] Lan TN. Utilisation de l'essai au bleu de méthylène en terrassement routier [Use of Methylene Blue test in Road earthworks]. Bull Labo P. 1981;5-16. 
[32] Beixing L, Mingkai Z, Jiliang W. Effect of the Methylene Blue Value of Manufactured Sand on Performances of Concrete. J. Adv. Concr. Technol. 2011;9:127-132.

[33] Lorenzo GA, Bergado DT. Fundamental Parameters of Cement-Admixed Clay-New Approach. J. Geotech. Geoenvironmental Eng. 2004;130:1042-1050.

[34] Dermatas D, Dutko P, Balorda-Barone J, et al. Evaluation of engineering properties of cement treated Hudson River dredged sediments for reuse as fill material. J. Mar. Environ. Eng. 2003;7:101-124.

[35] Perret P. Contribution à l'étude de la stabilisation des sols fins par la chaux: étude globale du phénomène et applications [Contribution to the study of stabilization of fine soils by lime: a global study of the phenomenon and applications] [Dissertation]. [IFSTTAR]; 1977.

[36] Locat J, Bérubé M-A, Choquette M. Laboratory investigations on the lime stabilization of sensitive clays: shear strength development. Can. Geotech. J. 1990;27:294-304.

[37] Tremblay H, Leroueil S, Locat J. Mechanical improvement and vertical yield stress prediction of clayey soils from eastern Canada treated with lime or cement. Can. Geotech. J. 2001;38:567-579.

[38] Chew SH, Kamruzzaman AHM, Lee FH. Physicochemical and Engineering Behavior of Cement Treated Clays. J. Geotech. Geoenvironmental Eng. 2004;130:696-706.

[39] Pollard SJT, Montgomery DM, Sollars CJ, et al. Organic compounds in the cement-based stabilisation/ solidification of hazardous mixed wastes-Mechanistic and process considerations. J. Hazard. Mater. 1991;28:313-327.

[40] Wang D, Zentar R, Abriak NE, et al. Experimental investigation on consistency limits of cement and lime-stabilized marine sediments. Environ. Technol. 2012;33:1197-1205.

[41] Croisé R. Traitement des sols aux liants hydrauliques [Soil treatment with hydraulic binders]. Rev. For. Fr. 1964;477-438.

[42] Wang D, Abriak NE, Zentar R. Strength and deformation properties of Dunkirk marine sediments solidified with cement, lime and fly ash. Eng. Geol. 2013;166:90-99.

[43] Cabane N, Fouletier M, Gaudon P. Sols traités à la chaux et aux liants hydrauliques: Contribution à l'identification et â $Y$ 'analyse des éléments perturbateurs de la stabilisation [Dissertation]. [SaintEtienne]: University Jean Monnet-Saint-Etienne; 2004.

[44] Diamond S, Kinter EB. Mechanisms of soil-lime stabilisation. Highw. Res. Rec. 1965;83-102.

[45] Eades J, JFP N, Grim R. Formation of new minerals with lime stabilisation as proven by field experiments in virginia. Highw. Res. Board Bull. 1962. p. 31-39.

[46] Banoune B, Melbouci B, Rosquoët F, et al. Treatment of river sediments by hydraulic binders for valorization in road construction. Bull. Eng. Geol. Environ. 2016;1-13.

[47] ACI Committee 232 AC 232. Use of Fly Ash in Concrete. Farmington Hills, Michigan, USA, American Concrete Institute: 41; 2004. p. 41.

[48] (ASTM) American Society for Testing and Materials. Standard Specification for Coal Fly Ash and Raw or Calcined Natural Pozzolan for Use as a Mineral Admixture in Concrete [Internet]. Philadelphia, USA: 4; 2001 [cited 2016 Jul 14]. Available from: http://www.astm.org/Standards/C618.htm. 
[49] Silitonga E. Valorisation des sédiments marins contaminés par solidification/stabilisation à base de liants hydrauliques et de fumée de silice [Valorisation of marine sediments contaminated by solidification / stabilization based on hydraulic binders and silica fume] [Dissertation]. [Caen]: University of Caen; 2010.

[50] McKennon JT, Hains NL, Hoffman DC. Applying lime to promote pozzolanic reaction between native silica and free alumina in the clay. 1994. p. 6.

[51] Kalkan E. Influence of silica fume on the desiccation cracks of compacted clayey soils. Appl. Clay Sci. 2009;43:296-302.

[52] Zentar R, Dubois V, Abriak NE. Mechanical behaviour and environmental impacts of a test road built with marine dredged sediments. Resour. Conserv. Recycl. 2008;52:947-954.

[53] Liang Y. Co-valorisation de sédiments et de sols fins par apport de liants et de fibres [Co-recovery of sediments and fine soils by adding binders and fibers] [Dissertation]. [Caen]: University of Caen; 2012.

[54] Loudia M. Etude du comportement mécanique d'un sédiment marin traité [Study of the mechanical behavior of a treated marine sediment] [Master thesis]. [IFSTTAR Nantes]: University of Normandy; 2015.

[55] Munck R. La co-valorisation de matériaux appliquée aux sédiments de dragage [Co-valorization of materials applied to dredged sediments] [Master thesis]. [IFSTTAR Nantes]: University of Normandy; 2015.

[56] Nuzzo R. Statistical errors. Nature. 2014;506:150-152.

[57] Maherzi W, Abdelghani FB. Dredged Marine Sediments Geotechnical Characterisation for Their Reuse in Road Construction. Eng. J. 2014;18:27-37. 
First step: Identification of input parameters

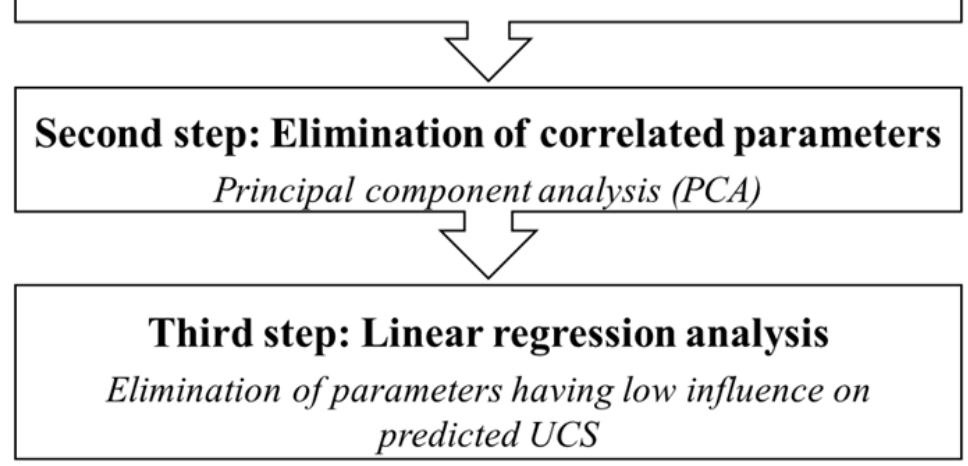

Figure 1. Followed steps to perform multivariate regression analysís 


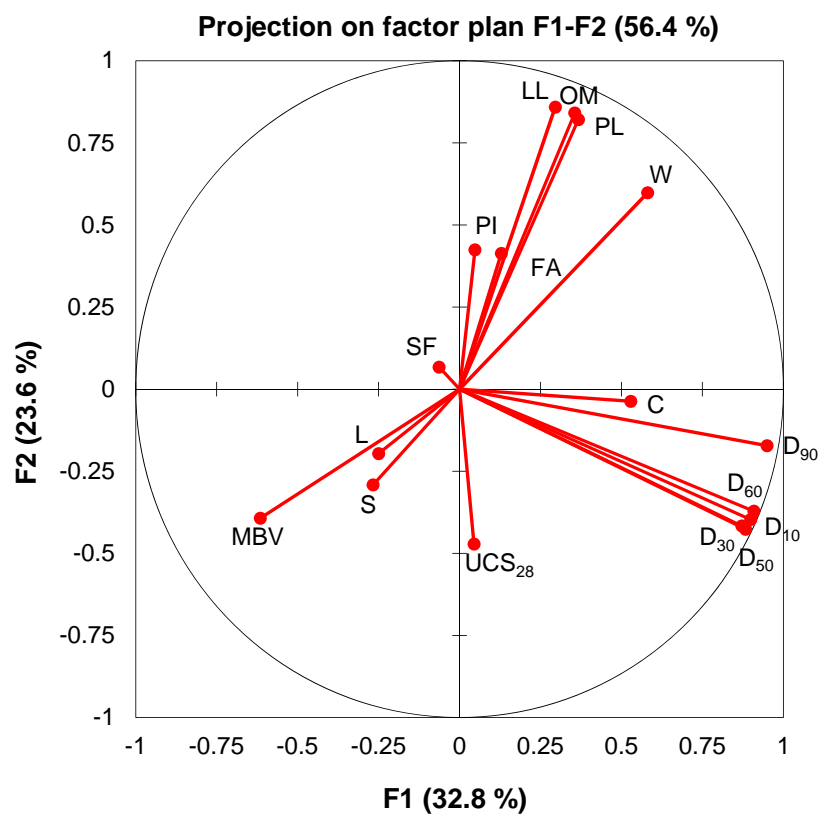

(a)

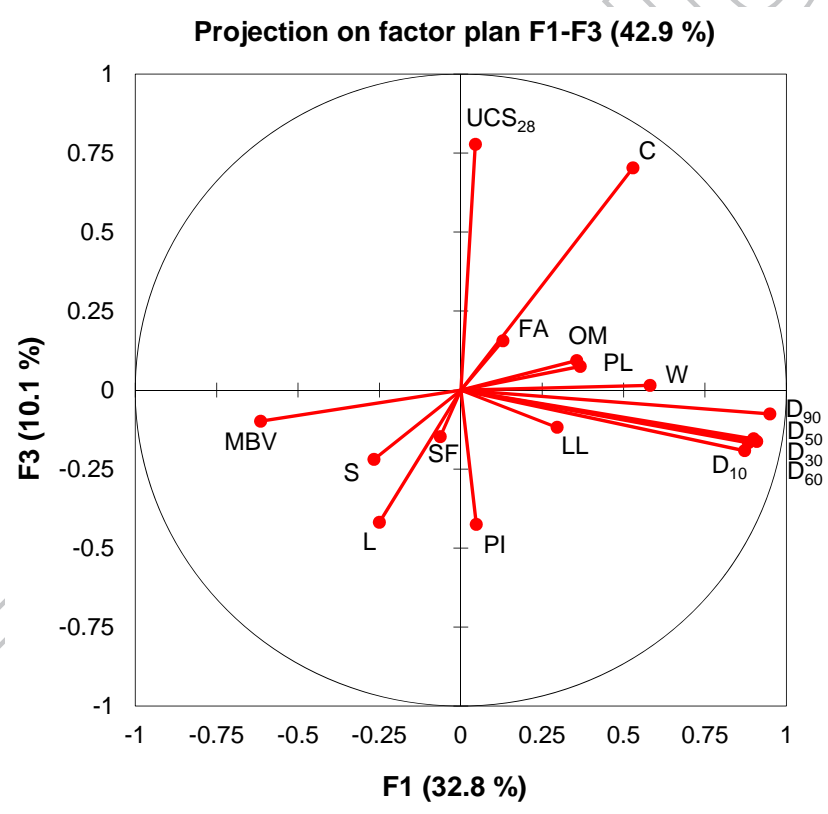

(b) 


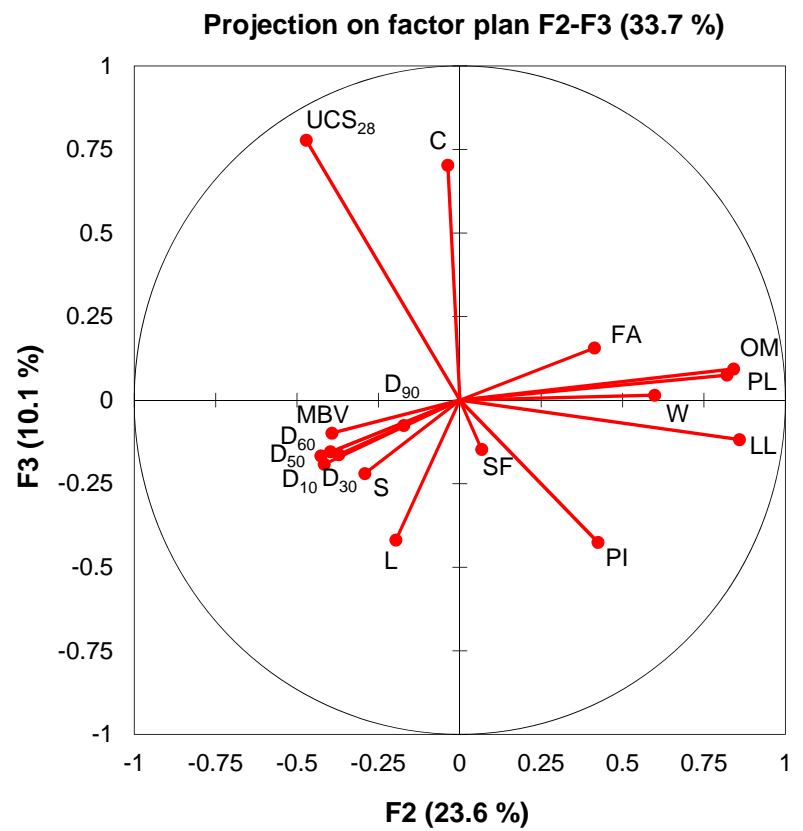

(c)

Figure 2. PCA projections (a) factor plan 1-2; (b) factor plan 1-3; (c) factor plan 2-3 


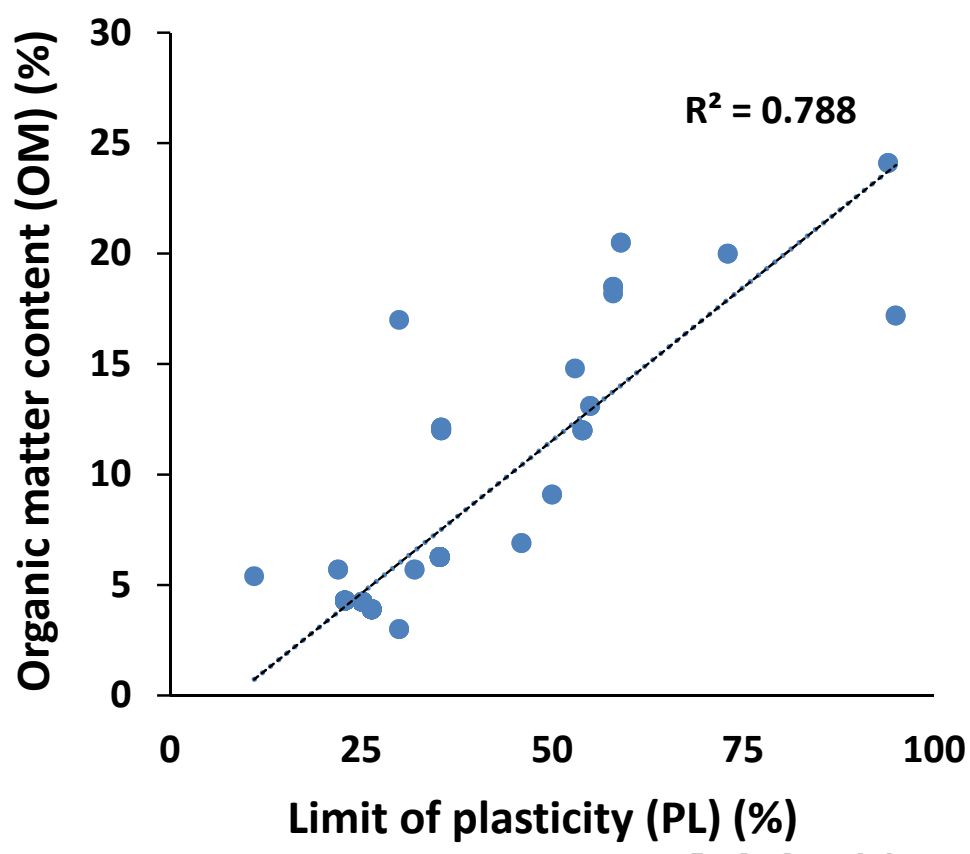

(a)

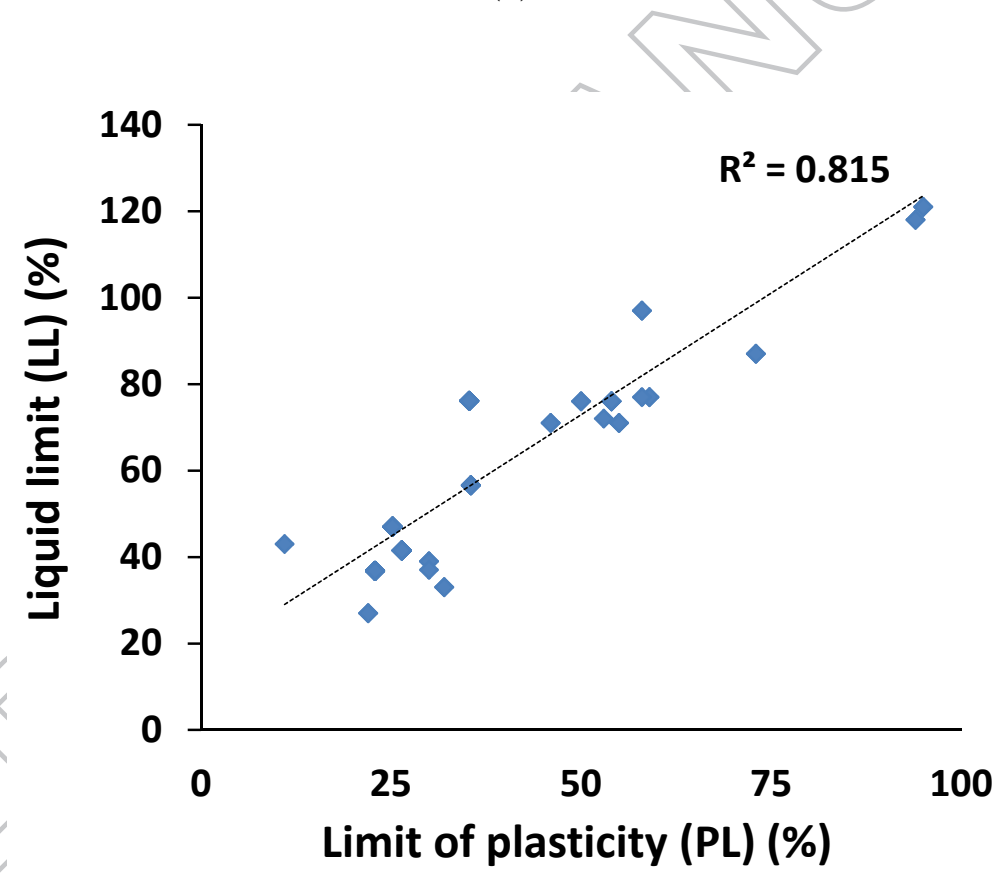

(b)

Figure 3. Correlations between: a) PL and OM; b) PL and LL 

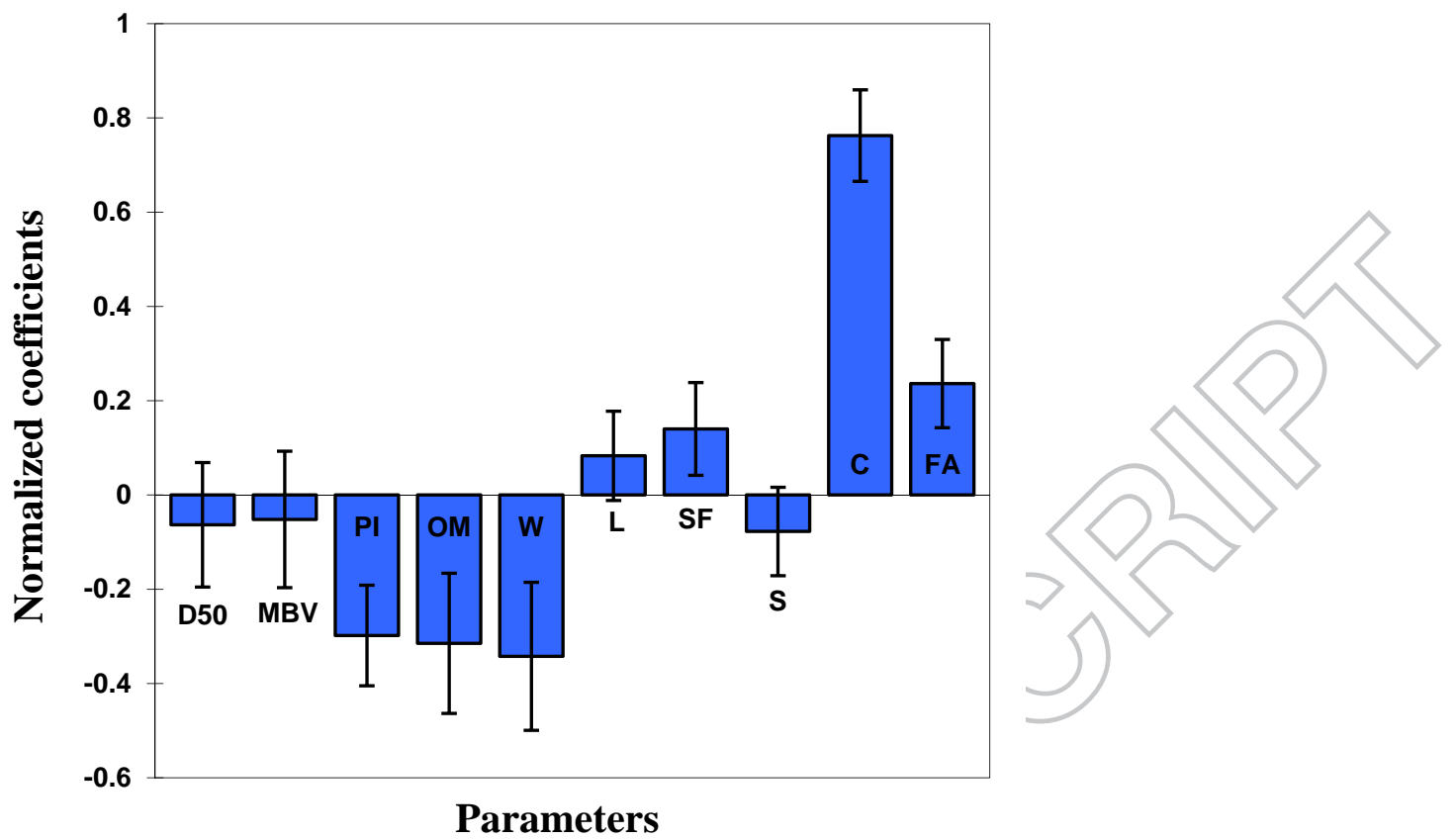

Figure 4. Normalized coefficients of regression 1 (with 95\% interval of confidence) 

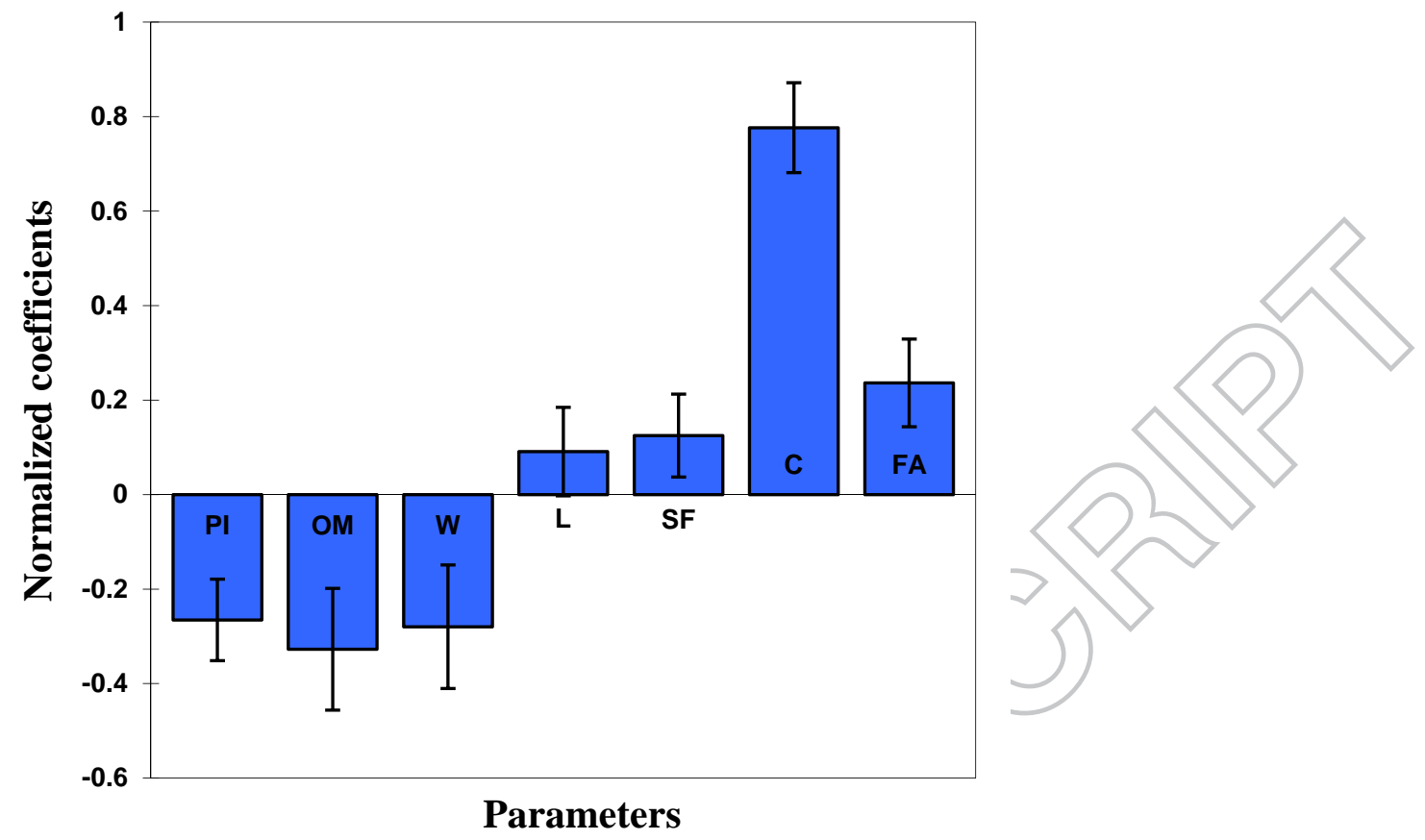

Figure 5. Normalized coefficients of regression 2 (with 95\% interval of confidence) 


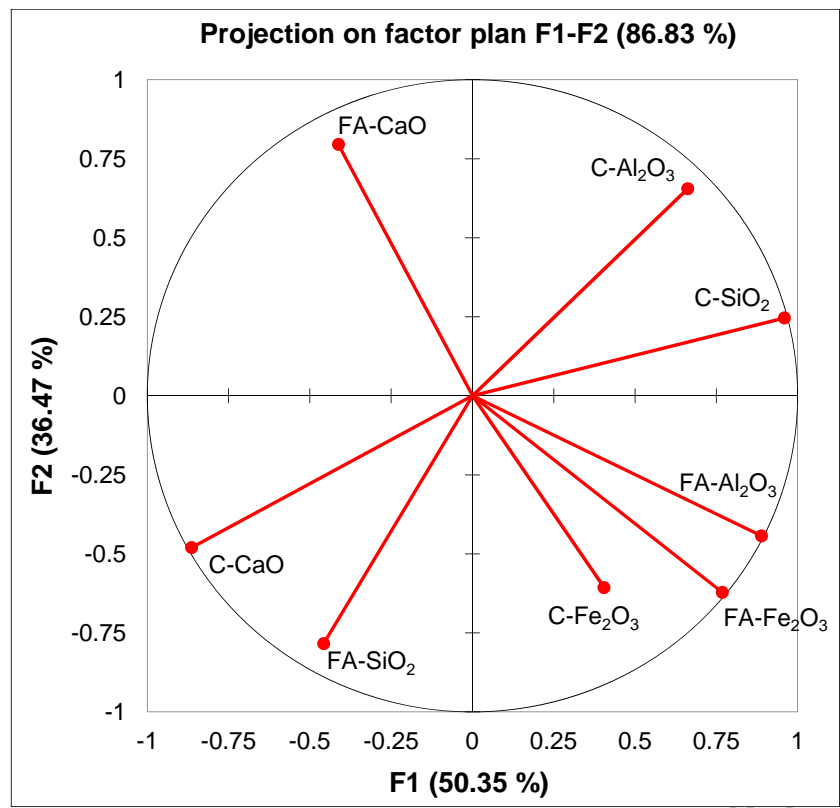

Figure 6. Cement and lime oxides PCA projection, factor plan 1-2

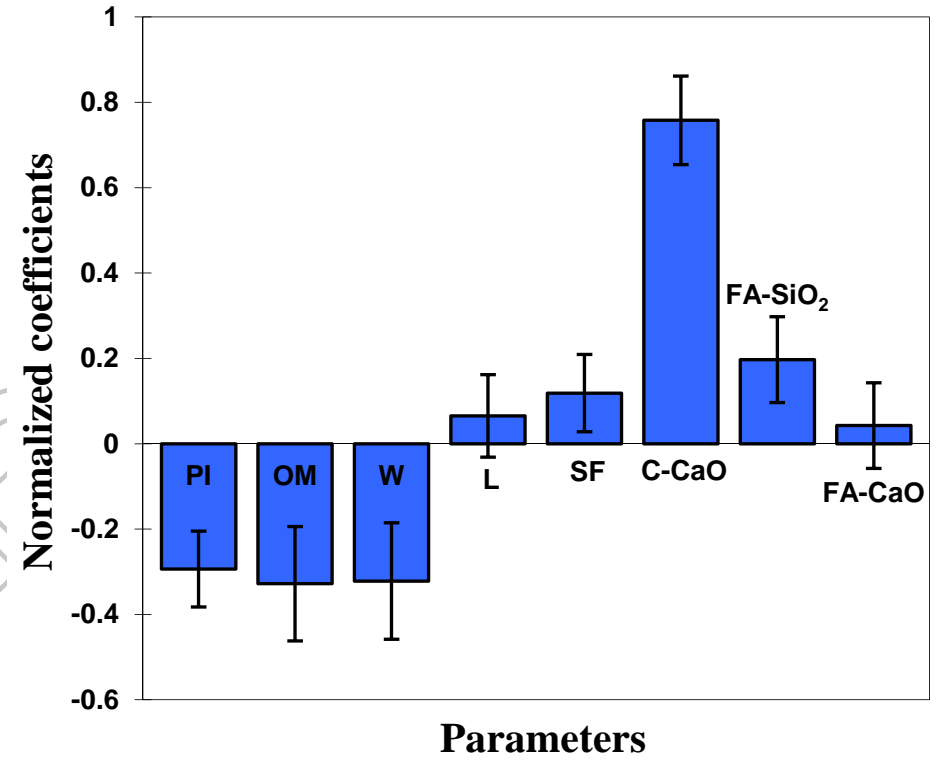

Figure 7. Normalized coefficients of regression 3 (with 95\% interval of confidence) 


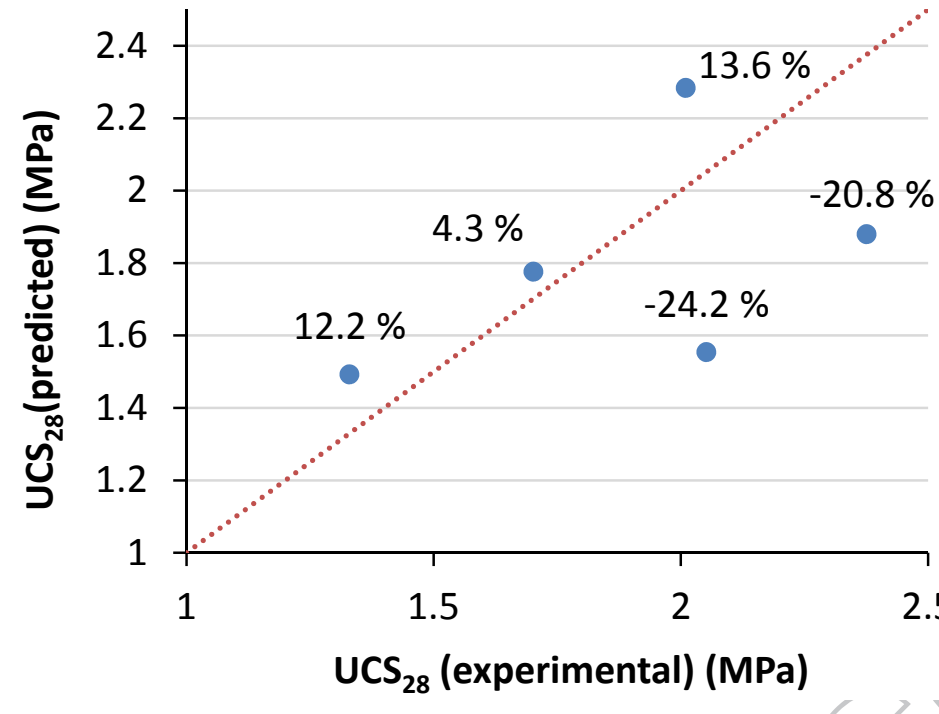

Figure 8. Validation of equation 6; $\mathrm{UCS}_{28}$ (predicted) vs $\mathrm{UCS}_{28}$ (experimental) 


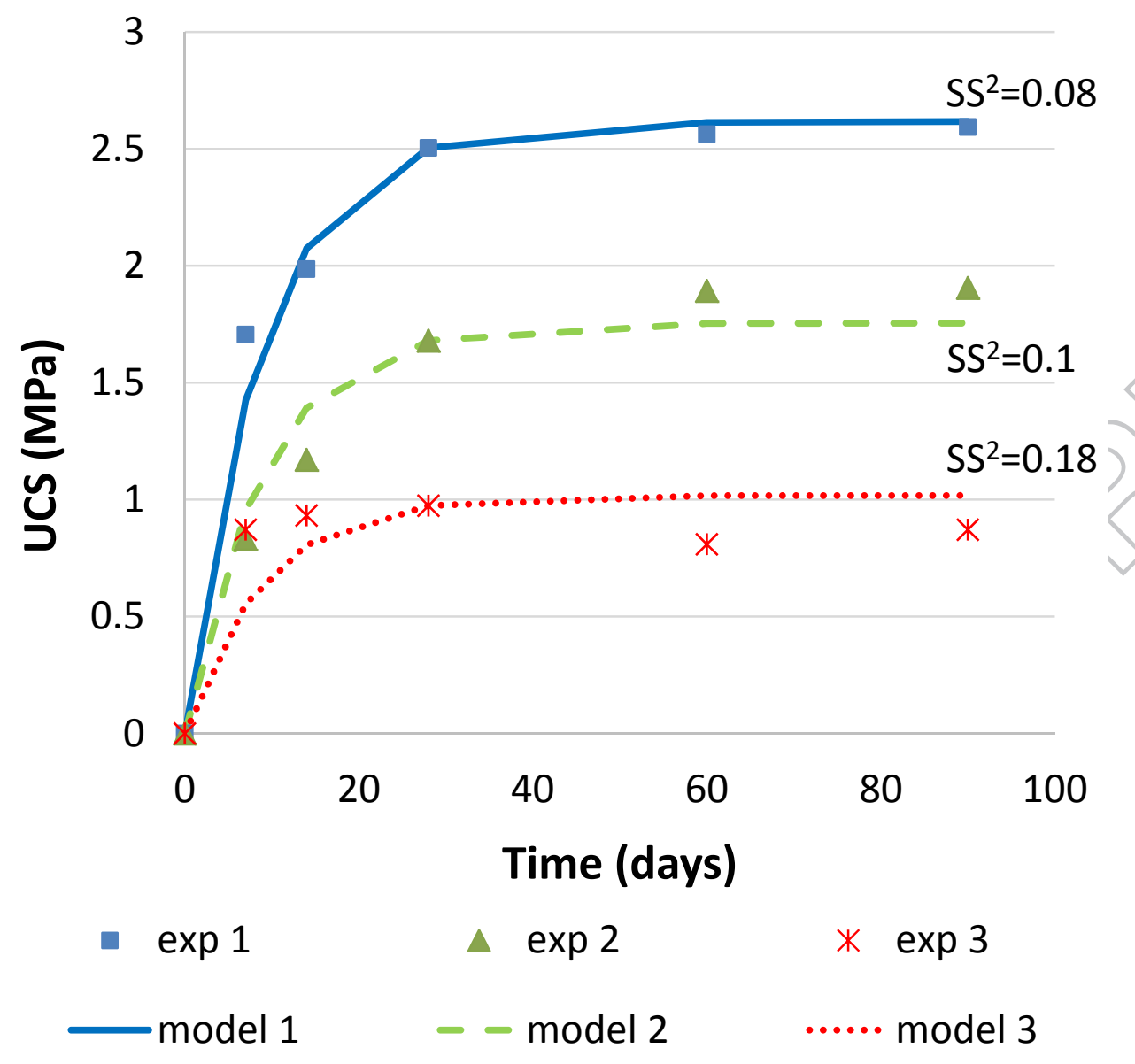

Figure 9. Modelisation of UCS development of treated sediments over time 
Table 1. Input parameters

\begin{tabular}{llll}
\hline & Parameter & Symbol & Range \\
\hline Properties of raw sediments & Grain size distribution & $\mathrm{D}_{10}, \mathrm{D}_{30}, \mathrm{D}_{50}, \mathrm{D}_{60}, \mathrm{D}_{90}$ & $\mathrm{D}_{50}: 7.3-86.7$ \\
& Methylene blue value & $\mathrm{MBV}$ & $\mu \mathrm{m}$ \\
& Organic matter & $\mathrm{OM}$ & $0.7-4.3 \mathrm{~g} / 100 \mathrm{~g}$ \\
& Atterberg limits & $\mathrm{PI}, \mathrm{LL}, \mathrm{PL}$ & $3-24.1 \%$ \\
\multirow{3}{*}{ Treatment } & Water & $\mathrm{W}$ & $\mathrm{PI}: 1-40.8$ \\
& Lime & $\mathrm{L}$ & \\
& Fly ash & FA & $0-17.6 \%$ \\
& Cement & $\mathrm{C}$ & $0-10 \%$ \\
& Silica fume & $\mathrm{SF}$ & $0-17.6 \%$ \\
& Sand & $\mathrm{S}$ & $0-10 \%$ \\
Mechanical resistance & Experimental UCS (28 days) & $\mathrm{UCS}_{28}$ & $0-34.2 \%$ \\
& & & $0.28-4.12 \mathrm{MPa}$ \\
\hline
\end{tabular}

Table 2. Correlated parameters

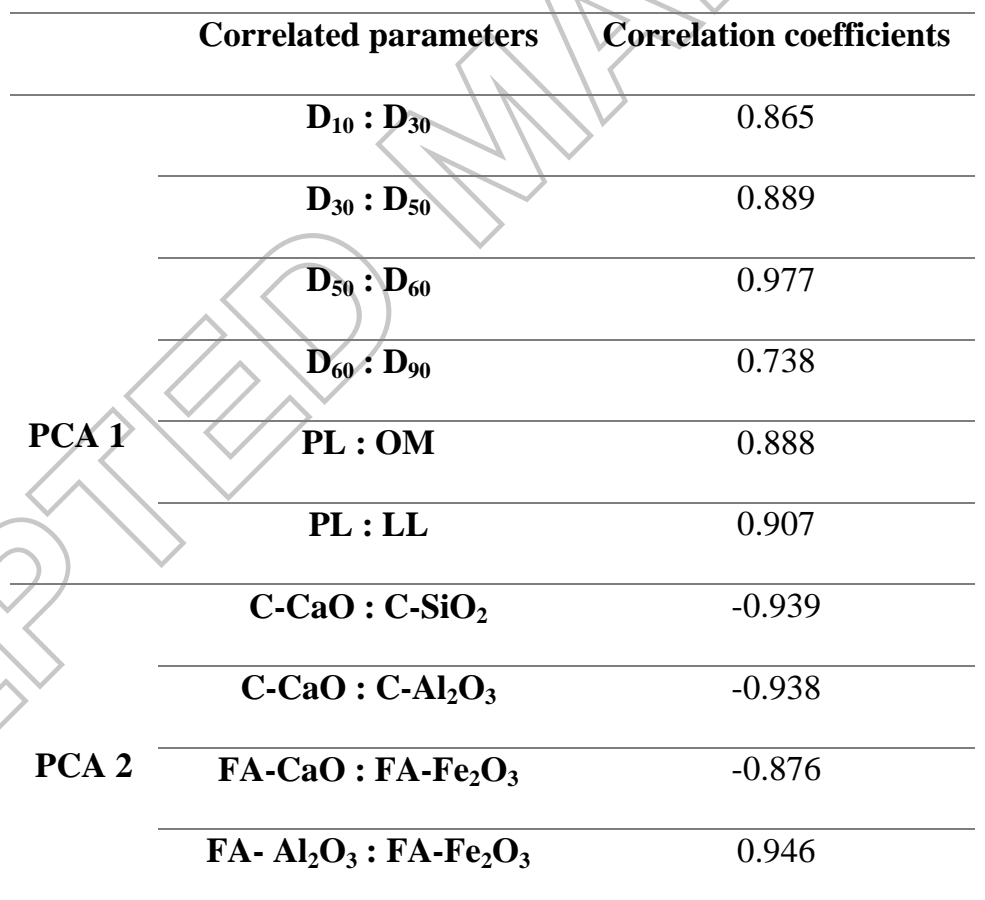


Table 3. Results of the 3 performed regressions

\begin{tabular}{|c|c|c|c|c|c|c|}
\hline Regression & \multicolumn{2}{|c|}{1} & \multicolumn{2}{|c|}{2} & \multicolumn{2}{|c|}{3} \\
\hline Adjusted $R^{2}$ & \multicolumn{2}{|c|}{0.765} & \multicolumn{2}{|c|}{0.764} & \multicolumn{2}{|c|}{0.751} \\
\hline \multirow[t]{2}{*}{ RMSE } & \multicolumn{2}{|c|}{0.316} & \multicolumn{2}{|c|}{0.317} & \multicolumn{2}{|c|}{0.326} \\
\hline & Coefficients & p-values & Coefficients & p-values & Coefficien & p-values \\
\hline Constant & 2.39 & $<0.0001$ & 2.05 & $<0.0001$ & 2.16 & $<0.0001$ \\
\hline $\mathbf{D}_{50}$ & -0.003 & 0.344 & & & & \\
\hline MBV & -0.031 & 0.481 & & & & \\
\hline PI & -0.023 & $<0.0001$ & -0.02 & $<0.0001$ & -0.023 & $<0.0001$ \\
\hline $\mathbf{O M}$ & -0.042 & $<0.0001$ & -0.044 & $<0.0001$ & -0.044 & $<0.0001$ \\
\hline W & -0.024 & $<0.0001$ & -0.019 & $<0.0001$ & -0.022 & $<0.0001$ \\
\hline $\mathbf{L}$ & 0.017 & 0.085 & 0.019 & 0.056 & 0.013 & 0.185 \\
\hline SF & 0.097 & 0.006 & 0.086 & 0.0065 & 0.082 & 0.011 \\
\hline $\mathbf{S}$ & -0.007 & 0.105 & & & & \\
\hline C & 0.138 & $<0.0001$ & 0.14 & $<0.0001$ & & \\
\hline FA & 0.043 & $<0.0001$ & 0.043 & $<0.0001$ & & \\
\hline $\mathrm{C}-\mathrm{CaO}$ & & & & & 0.255 & $<0.0001$ \\
\hline $\mathrm{FA}_{-\mathrm{SiO}_{2}}$ & & & & & 0.088 & 0 \\
\hline FA-CaO & & & & & 0.024 & 0.402 \\
\hline
\end{tabular}




\begin{tabular}{|c|c|c|c|c|c|c|c|c|c|c|c|c|c|c|c|c|c|}
\hline MIIX IV & $D_{10}$ & $\mathrm{D}_{30}$ & $\mathrm{D}_{50}$ & $D_{60}$ & $\mathrm{D}_{90}$ & IVIDV & LL & PL & PI & OIVI & $\mathrm{w}$ & L & SF & & $\tau$ & & $\pi$ \\
\hline 43 & 7 & $\angle L$ & 36.4 & 46.5 & 108 & 2.0 & 36.8 & $\angle 2.9$ & 13.9 & 4.3 & 12.0 & 0.4 & U & & & & 1.48 \\
\hline 44 & T & $\angle 2$ & 30.4 & 40.5 & 108 & 2.0 & 30.8 & $\angle L .9$ & 13.9 & 4.3 & 12.8 & 8.1 & U & & & & 1.5 \\
\hline 45 & 7 & $\angle L$ & 36.4 & 46.5 & 108 & 2.0 & 36.8 & $\angle 2.9$ & 13.9 & 4.3 & 13.1 & II.I & & & & & 1.55 \\
\hline 40 & 7 & $\angle L$ & 36.4 & 40.5 & 108 & 2.0 & 30.8 & $\angle L .9$ & 13.9 & 4.3 & 13.3 & 13.0 & & & U & U & 1.58 \\
\hline 41 & 7 & $\angle L$ & 36.4 & 40.5 & 108 & 2.0 & 36.8 & $\angle L .9$ & 13.9 & 4.3 & 13.5 & & & & V & U & $1 . / 2$ \\
\hline 48 & I & $\angle 2$ & 36.4 & 46.5 & 108 & 2.0 & 36.8 & $\angle L .9$ & 13.9 & 4.3 & 12 & & U & U & 2 & U & 2.12 \\
\hline 49 & 7 & $\angle L$ & 36.4 & 40.5 & 108 & 2.0 & 30.8 & $\angle 2.9$ & 13.9 & 4.3 & & & & o & 4.2 & U & 2.5 \\
\hline 50 & 1 & $\angle 2$ & 36.4 & 40.5 & 108 & 2.0 & 30.8 & $\angle L .9$ & 13.9 & & & 0 & O & U & 0.4 & U & 2.01 \\
\hline 51 & 7 & $\angle L$ & 36.4 & 46.5 & 108 & 2.0 & 36.8 & $\angle 2.9$ & 13.9 & 4.3 & 15 & U & U & U & 8.1 & U & 2.14 \\
\hline 52 & 7 & $\angle 2$ & 36.4 & 40.5 & 108 & 2.0 & 30.8 & $\angle L .9$ & 13.9 & 4.5 & 13.4 & J & V & U & II.I & U & 2.83 \\
\hline 53 & 7 & $\angle L$ & 36.4 & 40.5 & 108 & 2.0 & 30.8 & $2<.9$ & 5.9 & 4.3 & 13.1 & U & V & U & 13.0 & U & 3.28 \\
\hline 54 & $T$ & $\angle L$ & 36.4 & 40.5 & 108 & 2.0 & 30.8 & & 15.9 & 4.3 & 14.1 & O & U & U & 17.0 & U & 4.12 \\
\hline 55 & T & $\angle L$ & 36.4 & 40.5 & 108 & 2.0 & 30.8 & $2 \angle$ & 13.9 & 4.3 & 14 & 2.2 & U & 5.4 & U & U & 1.9 \\
\hline 50 & 7 & $\angle L$ & 36.4 & 40.5 & 108 & & 30.8 & $\angle L .9$ & 13.9 & 4.3 & 13.2 & 2.3 & V & 11.4 & V & U & 1.84 \\
\hline 5 & 7 & $\angle L$ & 36.4 & 46.5 & 108 & & 30 & 22.9 & 13.9 & 4.3 & 12.5 & 2.4 & 0 & 18.1 & U & U & 1.01 \\
\hline 58 & 7 & $\angle 2$ & 30.4 & 40.5 & & & 56.8 & $\angle 2.9$ & 13.9 & 4.3 & $11 . /$ & 2.0 & o & $\angle 5.0$ & V & U & 1.51 \\
\hline 59 & T & $\angle L$ & 30.4 & & & 2.0 & 30.8 & $\angle L .9$ & 13.9 & 4.3 & 11 & 2.1 & U & 34.2 & U & U & 1.40 \\
\hline סण & $z$ & 5.1 & 12 & & 78.4 & 4.3 & 41 & 25.2 & $\angle 1.8$ & 4.2 & 21.1 & U & U & O & V & U & 1.18 \\
\hline 01 & 2 & 5.1 & & & 18.4 & 4.3 & 41 & 25.2 & $\angle 1.8$ & 4.2 & 23.0 & 3.2 & o & v & 2.1 & U & 1.53 \\
\hline 02 & 2 & 5.1 & & & 78.4 & 4.3 & 41 & 25.2 & $\angle 1.8$ & 4.2 & $\angle 4$ & 3.2 & 1.1 & O & 2.1 & U & 1.53 \\
\hline 03 & 2 & 5.1 & 12.1 & 17.4 & 18.4 & 4.3 & 41 & 25.2 & $\angle 1.8$ & 4.2 & $\angle 1.0$ & 3.3 & 0 & 5.0 & 2.2 & U & 1.83 \\
\hline
\end{tabular}




\begin{tabular}{|c|c|c|c|c|c|c|c|c|c|c|c|c|c|c|c|c|}
\hline $\mathrm{D}_{10}$ & $\mathrm{D}_{30}$ & $\mathrm{D}_{50}$ & $\mathrm{D}_{60}$ & $\mathrm{D}_{90}$ & MBV & LL & PL & PI & $\mathrm{OM}$ & $\mathrm{W}$ & $\mathrm{L}$ & SF & $S$ & $\mathrm{C}$ & FA & $\mathrm{UCS}_{28}$ \\
\hline 2 & 5.7 & 12.1 & 17.4 & 78.4 & 4.3 & 47 & 25.2 & 21.8 & 4.2 & 20.3 & 3.4 & 1.1 & 5.6 & 2.2 & 0 & 1.83 \\
\hline 2 & 5.7 & 12.1 & 17.4 & 78.4 & 4.3 & 47 & 25.2 & 21.8 & 4.2 & 18.3 & 3.5 & 0 & 11.8 & 2.4 & 0 & \\
\hline 2 & 5.7 & 12.1 & 17.4 & 78.4 & 4.3 & 47 & 25.2 & 21.8 & 4.2 & 19.5 & 3.6 & 1.2 & 11.9 & 2.4 & & \\
\hline 2 & 5.7 & 12.1 & 17.4 & 78.4 & 4.3 & 47 & 25.2 & 21.8 & 4.2 & 15.4 & 3.8 & 0 & 18.8 & 2.5 & 0 & \\
\hline 2 & 5.7 & 12.1 & 17.4 & 78.4 & 4.3 & 47 & 25.2 & 21.8 & 4.2 & 17.8 & 3.8 & 1.3 & 19 & & & 1.78 \\
\hline 2 & 5.7 & 12.1 & 17.4 & 78.4 & 4.3 & 47 & 25.2 & 21.8 & 4.2 & 24 & 3.2 & 1.1 & & & 0 & 1.33 \\
\hline 2 & 5.7 & 12.1 & 17.4 & 78.4 & 4.3 & 47 & 25.2 & 21.8 & 4.2 & 24 & 3.2 & & & 2,1 & 0 & 1.33 \\
\hline 2 & 5.7 & 12.1 & 17.4 & 78.4 & 4.3 & 47 & 25.2 & 21.8 & 4.2 & 19.7 & 3.4 & & 5.6 & 2.2 & 0 & 1.18 \\
\hline 2 & 5.7 & 12.1 & 17.4 & 78.4 & 4.3 & 47 & 25.2 & 21.8 & 4.2 & 19.7 & 3.4 & & 5.6 & 2.2 & 0 & 1.19 \\
\hline 2 & 5.7 & 12.1 & 17.4 & 78.4 & 4.3 & 47 & 25.2 & 21.8 & 4.2 & 17.3 & .8 & $1.3^{*}$ & 19 & 2.5 & 0 & 1.52 \\
\hline 2 & 5.7 & 12.1 & 17.4 & 78.4 & 4.3 & 47 & 25.2 & 21.8 & 4.2 & 17.3 & 3.8 & $1.3^{* *}$ & 19 & 2.5 & 0 & 1.42 \\
\hline 2 & 5.7 & 12.1 & 17.4 & 78.4 & 4.3 & 47 & 25.2 & 21. & 4.2 & 23.6 & 3.2 & 0 & 0 & 2.1 & 4.2 & 1.76 \\
\hline 2 & 5.7 & 12.1 & 17.4 & 78.4 & 4.3 & 47 & 25 & & 4.2 & 23.6 & 3.2 & 0 & 0 & 2.1 & 8.4 & 1.83 \\
\hline 2 & 5.7 & 12.1 & 17.4 & 78.4 & 4.3 & 47 & & & 4.2 & 23.6 & 3.2 & 0 & 0 & 2.1 & 4.2 & 1.55 \\
\hline 2 & 5.7 & 12.1 & 17.4 & 78.4 & 4.3 & & & 8 & 4.2 & 23.6 & 3.2 & 0 & 0 & 2.1 & 8.4 & 1.91 \\
\hline 2 & 5.7 & 12.1 & 17.4 & 78.4 & & 47 & 25,2 & 21.8 & 4.2 & 19.8 & 3.3 & 0 & 5.6 & 2.2 & 4.4 & 1.95 \\
\hline 2 & 5.7 & 12.1 & 17.4 & 78 & & 47 & 25.2 & 21.8 & 4.2 & 19.8 & 3.3 & 0 & 5.6 & 2.2 & 8.9 & 2.2 \\
\hline 2 & 5.7 & 12.1 & 17.4 & 77. & & 47 & 25.2 & 21.8 & 4.2 & 19.8 & 3.3 & 0 & 5.6 & 2.2 & 4.4 & 1.88 \\
\hline 2 & 5.7 & 12.1 & 17.4 & 78.4 & 4.3 & 47 & 25.2 & 21.8 & 4.2 & 19.8 & 3.3 & 0 & 5.6 & 2.2 & 8.9 & 1.97 \\
\hline 2 & 5.7 & 12. & 17. & 78.4 & 4.3 & 47 & 25.2 & 21.8 & 4.2 & 17.6 & 3.8 & 0 & 18.8 & 2.5 & 5 & 2.11 \\
\hline 2 & 5.7 & 12. & 17.4 & 78.4 & 4.3 & 47 & 25.2 & 21.8 & 4.2 & 17.6 & 3.8 & 0 & 18.8 & 2.5 & 10 & 2.23 \\
\hline
\end{tabular}




\begin{tabular}{|c|c|c|c|c|c|c|c|c|c|c|c|c|c|c|c|}
\hline$D_{30}$ & $D_{50}$ & $D_{60}$ & $D_{90}$ & IVIDV & LL & PL & PI & OIVI & w & $L$ & SF & 5 & $c$ & FA & $U_{C S_{28}}$ \\
\hline 5.1 & 12.1 & $1 / .4$ & 78.4 & 4.3 & 41 & 25.2 & $\angle 1.8$ & 4.2 & 17.0 & 3.8 & 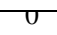 & 18.8 & 2.5 & 5 & 2.17 \\
\hline 5.1 & 12.1 & $1 / .4$ & 18.4 & 4.3 & 41 & 25.2 & 21.8 & 4.2 & 17.0 & 3.8 & U & 18.8 & 2.5 & 10 & 2 \\
\hline 5.1 & 12.1 & $1 / .4$ & 78.4 & 4.3 & 41 & 25.2 & 21.8 & 4.2 & 23.5 & 3.3 & 0 & 0 & 5.4 & 0 & $1 . / 2$ \\
\hline 5.1 & 12.1 & $1 / .4$ & 18.4 & 4.3 & 41 & 25.2 & $\angle 1.8$ & 4.2 & $\angle 4.4$ & 3.3 & 1.1 & U & 5.5 & U & 1.9 \\
\hline 5.1 & 12.1 & $1 / .4$ & 78.4 & 4.3 & 41 & 25.2 & $\angle 1.8$ & 4.2 & 23 & 3.4 & 0 & 5.1 & 5.1 & & \\
\hline 5.1 & 12.1 & $1 / .4$ & 18.4 & 4.3 & 41 & 25.2 & $\angle 1.8$ & 4.2 & 20.5 & 3.5 & 1.2 & 5.8 & 5.8 & & \\
\hline 5.1 & $I L .1$ & $1 / .4$ & 78.4 & 4.3 & 41 & 25.2 & $\angle 1.8$ & 4.2 & 10.8 & 3.1 & 0 & 12.2 & & & $1 . / 1$ \\
\hline 5.1 & 12.1 & $1 / .4$ & 18.4 & 4.3 & 41 & 25.2 & $\angle 1.8$ & 4.2 & 19.1 & 3.1 & 1.2 & & & & 1.81 \\
\hline 5.1 & 12.1 & 17.4 & 78.4 & 4.3 & 4I & 25.2 & 21.8 & 4.2 & 25 & 3.9 & & & .5 & U & 1.14 \\
\hline 5.1 & 12.1 & 17.4 & 78.4 & 4.3 & 41 & 25.2 & 21.8 & 4.2 & $\angle 0.2$ & 3.9 & & & 0.0 & U & 1.84 \\
\hline 5.1 & 12.1 & 17.4 & 18.4 & 4.3 & 47 & 25.2 & $\angle 1.8$ & 4.2 & $\angle L$ & J. & & U & L.I & U & 1.36 \\
\hline 5.1 & 12.1 & 17.4 & 18.4 & 4.3 & 41 & 25.2 & $\angle 1.8$ & 4.2 & & & & U & 2.1 & U & 1.4 \\
\hline 5.1 & 12.1 & 17.4 & 18.4 & 4.3 & $4 /$ & 25.2 & 21.8 & 4.2 & 20.0 & & U & 5.0 & 2.2 & 0 & 1.39 \\
\hline 5.1 & 12.1 & $1 / .4$ & 78.4 & 4.3 & 47 & 25.2 & 21.8 & & & 3.4 & 1.1 & 5.0 & 2.2 & U & 1.4 \\
\hline 5.1 & 12.1 & 17.4 & 78.4 & 4.3 & 47 & 25.2 & 21.8 & & & 3.5 & 0 & 11.8 & 2.4 & U & 1.1 \\
\hline 5.1 & 12.1 & 17.4 & 18.4 & 4.3 & 41 & 2 & & & 18.2 & 3.0 & 1.2 & 11.9 & 2.4 & U & 1.04 \\
\hline 5.1 & $1<.1$ & $1 / .4$ & 18.4 & 4.3 & & & & 4.2 & 18.3 & 3.8 & 0 & 18.8 & 2.5 & 0 & 1.2 \\
\hline 5.1 & 12.1 & 17.4 & 78.4 & 4.3 & & & 21.8 & 4.2 & $1 / .3$ & 3.8 & 1.3 & 19 & 2.5 & 0 & 1.28 \\
\hline 8.0 & 10 & $\angle L .1$ & 88 & & & & $\angle L$ & 12 & 33.9 & 3 & U & U & 5 & 10 & 1.41 \\
\hline 8.0 & 10 & ZL.I & 88 & & & & $\angle L$ & 12 & 34.8 & U & U & 10 & 5 & U & 1.25 \\
\hline 8.0 & 10 & $\angle L .1$ & 88 & & & 54 & $\angle L$ & 12 & 34.8 & U & 0 & 10 & 5 & 0 & 0.91 \\
\hline
\end{tabular}

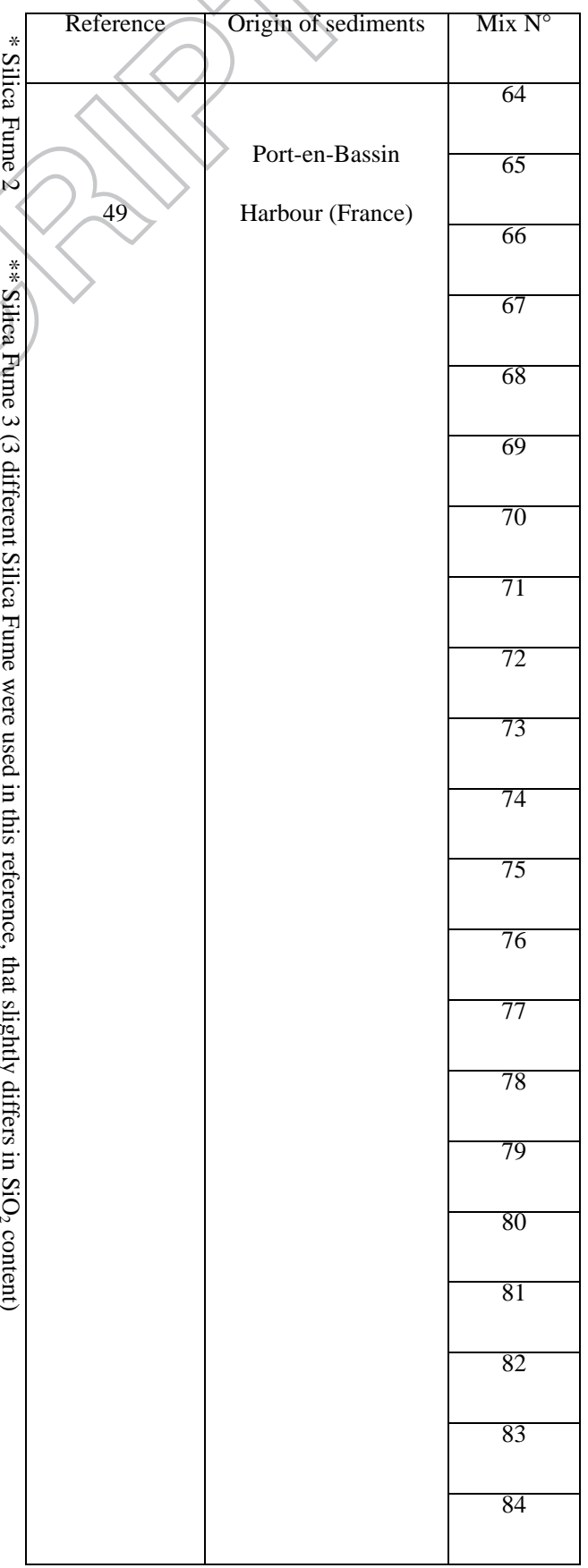




\begin{tabular}{|c|c|c|c|c|c|c|c|c|c|c|c|c|c|c|}
\hline $\mathrm{D}_{50}$ & $D_{60}$ & $D_{90}$ & MBV & LL & PL & PI & OM & W & $\mathrm{L}$ & SF & 5 & C & FA & $\mathrm{UCS}_{28}$ \\
\hline 16 & LL.I & 88 & & 76 & 54 & $\angle 2$ & 12 & 34.3 & 1.5 & $\sigma$ & U & 5 & 10 & 0.93 \\
\hline 14 & 25.1 & 251 & & 31 & 30 & 7 & 17 & 21.5 & 2 & U & U & 7 & $\sigma$ & 2.01 \\
\hline 40 & 62.1 & 282 & & 21 & $\angle L$ & 5 & 5.1 & 21.5 & 2 & 0 & U & 7 & U & 1.8 \\
\hline 40 & 62.1 & 282 & & 21 & $\angle L$ & 5 & 5.1 & 25.2 & 2 & U & O & 7 & 10 & \\
\hline 19 & 28.9 & 251 & & 33 & 32 & 1 & 5.1 & 45.9 & 2 & U & 0 & 7 & & \\
\hline 19 & 28.9 & 257 & & 33 & 32 & 1 & 5.1 & 42 & 2 & 0 & 0 & & & 2.3 \\
\hline 23 & 28.9 & $17 / 7$ & & 121 & 95 & 26 & 17.2 & 27.5 & 2 & 0 & U & & & 1.76 \\
\hline 23 & 28.9 & $1 / 1$ & & 121 & 95 & 26 & 11.2 & 25.2 & 2 & U & & & 10 & 1.98 \\
\hline 21 & 37.8 & 213 & & 77 & 58 & 19 & 18.2 & 45.5 & 0 & & & 0 & 0 & 1.05 \\
\hline 86.7 & 5 & 494 & & 71 & 59 & 18 & 20.5 & 27.5 & 2 & & & 7 & 0 & 1.45 \\
\hline 86.7 & 5 & 494 & & 71 & 59 & 18 & 20.5 & 25 & & 0 & 0 & 7 & 10 & 1.45 \\
\hline 36 & 56.3 & 251 & & 71 & 55 & 16 & 13.1 & & & U & o & 7 & U & 1.44 \\
\hline 36 & 56.3 & 251 & & 71 & 55 & 16 & & & 2 & 0 & U & 7 & 10 & 1.91 \\
\hline IT & 31.8 & 257 & & 118 & 94 & & & 45.9 & 2 & 0 & U & 7 & 0 & 0.3 \\
\hline I7 & 31.8 & 257 & & 118 & 94 & & & 42 & 2 & 0 & U & 7 & 10 & 0.85 \\
\hline 23 & 32.1 & $1 \angle 2$ & & 81 & & & $\angle O$ & 45.9 & 2 & 0 & 0 & 1 & 0 & 1.29 \\
\hline 23 & 32.1 & $1 \angle L$ & & & & 14 & 20 & 42 & 2 & $\sigma$ & U & 7 & 10 & 1.48 \\
\hline 21 & 30.5 & 101 & & 72 & & 19 & 14.8 & 45.9 & 2 & $\sigma$ & U & 7 & 0 & 0.12 \\
\hline 25 & 36.2 & $1 / 1$ & & & 58 & 39 & 18.5 & 45.9 & 2 & U & U & 7 & 0 & 0.91 \\
\hline
\end{tabular}

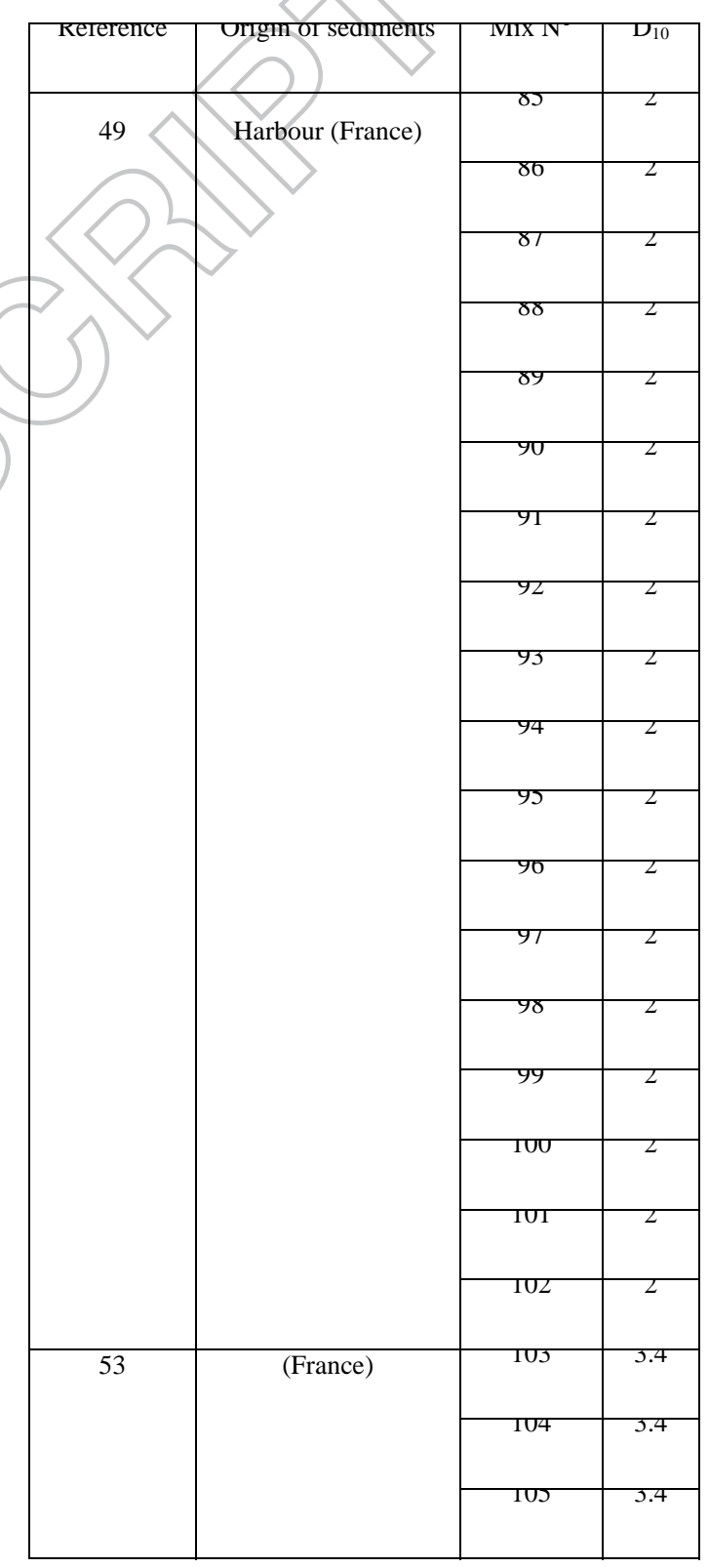




\begin{tabular}{|c|c|c|c|c|c|c|c|c|c|c|c|c|c|}
\hline$D_{60}$ & $D_{90}$ & IVIDV & LL & PL & PI & UIVI & w & $L$ & SF & 5 & C & $\mathrm{FA}$ & UCS 28 \\
\hline 78.7 & 223 & & 43 & 11 & 32 & 5.4 & 39.2 & 0 & 0 & 0 & 2 & 0 & 0.9 \\
\hline 36.2 & 177 & & 97 & 58 & 39 & 18.5 & 42 & 2 & 0 & 0 & 7 & 10 & 1.5 \\
\hline 59.0 & 105.9 & & 50.5 & 35.4 & ZI.I & IL.I & 33.8 & $\sigma$ & $\sigma$ & $\sigma$ & U & U & 0.25 \\
\hline 59.0 & 105.9 & & 50.5 & 35.4 & $\angle 1.1$ & 12.1 & 35.3 & U & U & U & 0.5 & 9.4 & 0.5 \\
\hline 59.0 & 105.9 & & 50.5 & 35.4 & ZI.I & IL.I & 34.1 & U & U & U & U & 9.9 & \\
\hline 59.0 & 105.9 & & 50.5 & 35.4 & ZI.I & IL.I & 30 & 2.2 & U & U & U & & \\
\hline 59.0 & $10 / .1$ & & 50.0 & 35.5 & ZI.I & $I L$ & 33.0 & U & $\sigma$ & U & o & & \\
\hline 59.0 & $10 / .1$ & & 50.0 & 35.5 & $\angle 1.1$ & 12 & 35.2 & 0 & U & U & & & \\
\hline 59.0 & $10 / .1$ & & 50.0 & 35.5 & ZI.I & 12 & 36.4 & 2.2 & $\sigma$ & & & & \\
\hline
\end{tabular}

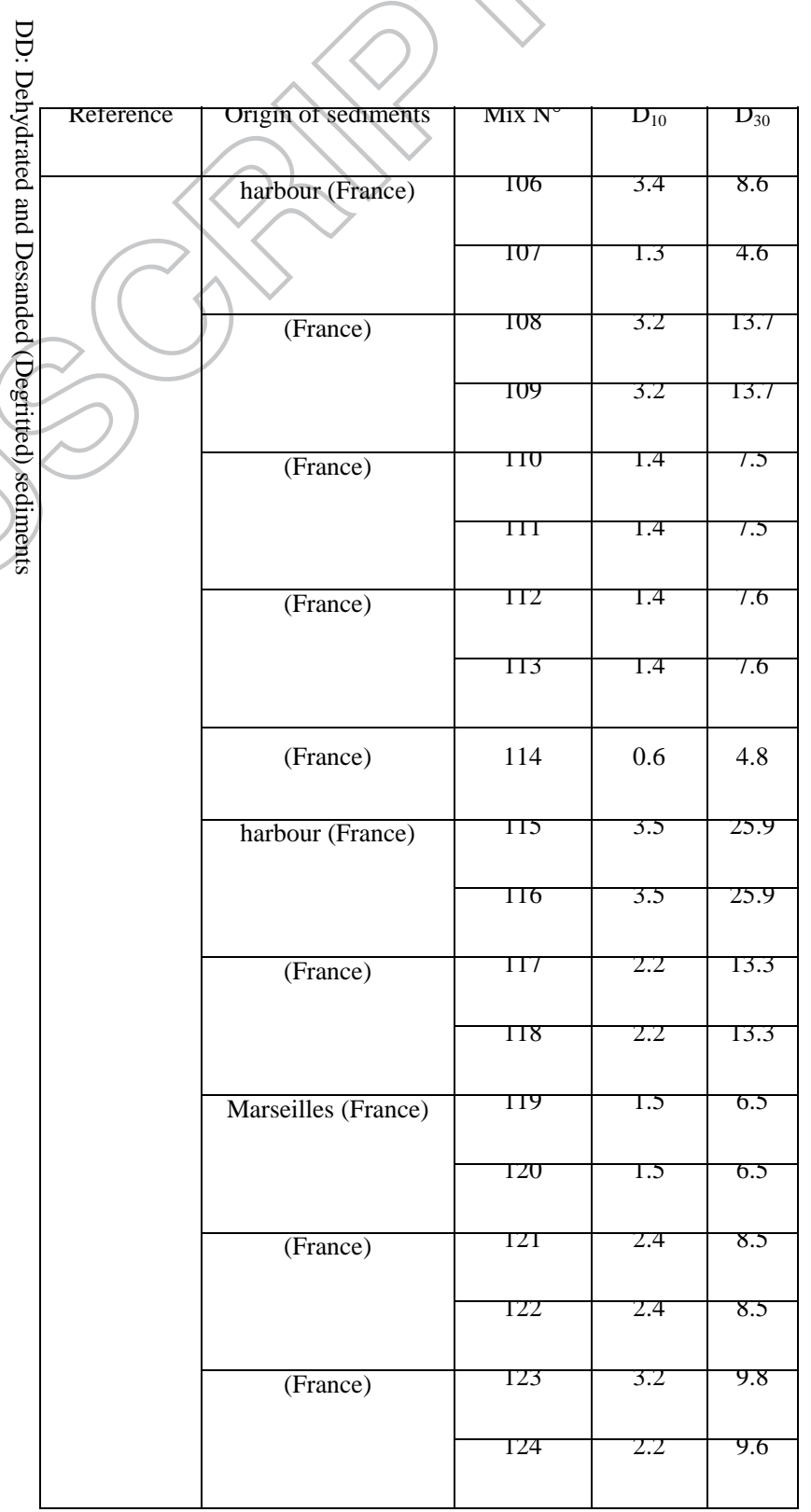




\section{Annex}

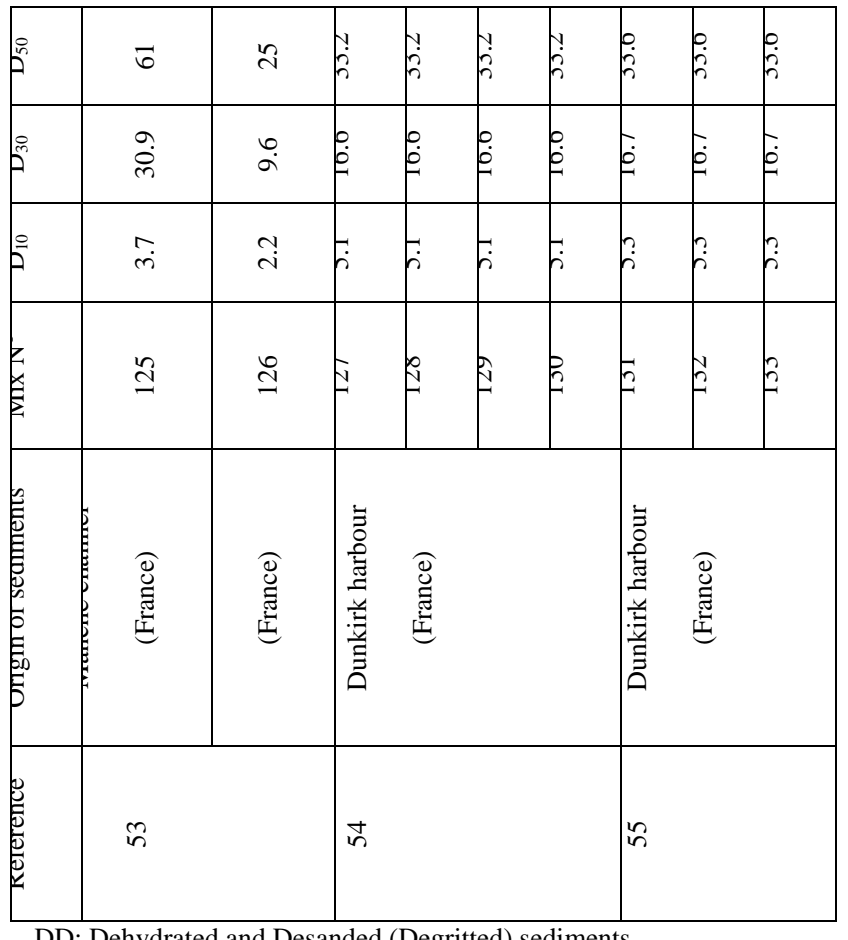

DD: Dehydrated and Desanded (Degritted) sediments

Table 5. Percentage of oxides in used Cement and Fly ash

\begin{tabular}{|c|c|c|c|c|c|c|c|c|}
\hline Reference & C-CaO & C-SiO & C- $-\mathrm{Al}_{2} \mathrm{O}_{3}$ & $\mathrm{C}-\mathrm{Fe}_{2} \mathrm{O}_{3}$ & FA-CaO & FA- $\mathrm{SiO}_{2}$ & FA-Al ${ }_{2} \mathbf{O}_{3}$ & $\mathrm{FA}^{-\mathrm{Fe}_{2} \mathrm{O}_{3}}$ \\
\hline 21 & 56.8 & 20.2 & 6.9 & & - & - & - & - \\
\hline 42 & 63.3 & 21.4 & 3.3 & 4 & 8.5 & 50 & 29 & 8.5 \\
\hline 46 & 56.8 & 20.2 & & 3.9 & - & - & - & - \\
\hline \multirow[t]{2}{*}{49} & 56.8 & & & 3.9 & 8.5 & 47.4 & 21.6 & 7.1 \\
\hline & & & & & 35.3 & 20.4 & 11.7 & 1.9 \\
\hline 53 & 56.8 & & 6.9 & 3.9 & 8.5 & 47.4 & 21.6 & 7.1 \\
\hline 54 & 76.5 & 11.7 & 2.4 & 3.9 & 17.7 & 63.2 & 9.3 & 3.3 \\
\hline 55 & & 11.7 & 2.4 & 3.9 & 17.7 & 63.2 & 9.3 & 3.3 \\
\hline
\end{tabular}

Table 6. Database used for validation of model

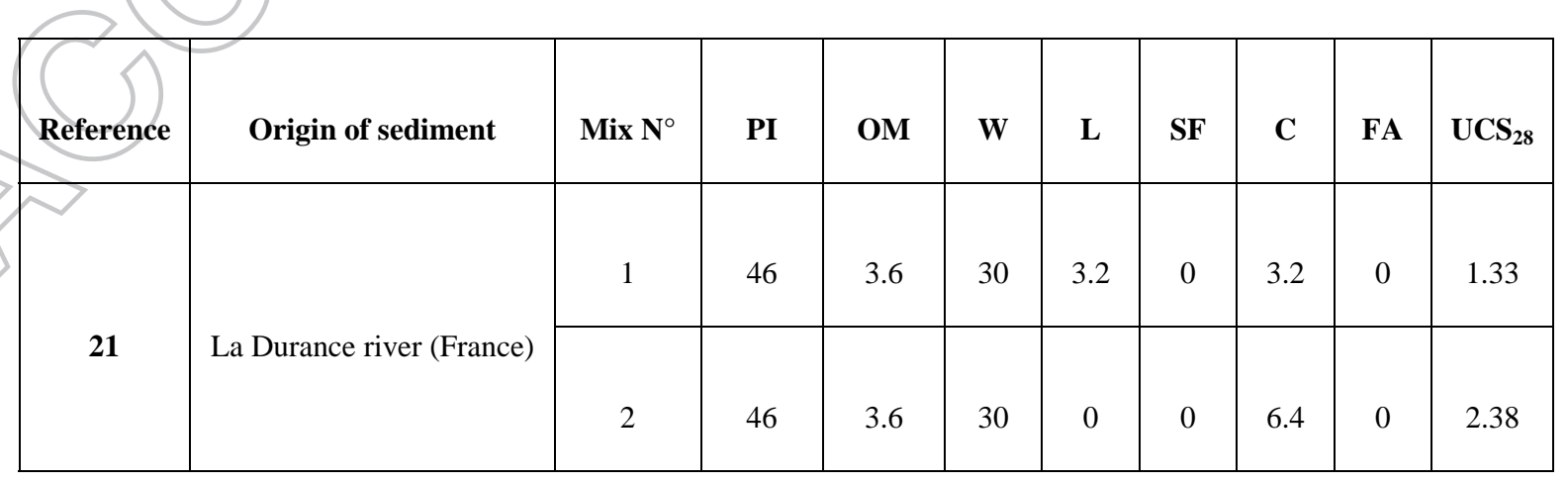




\section{Annex}

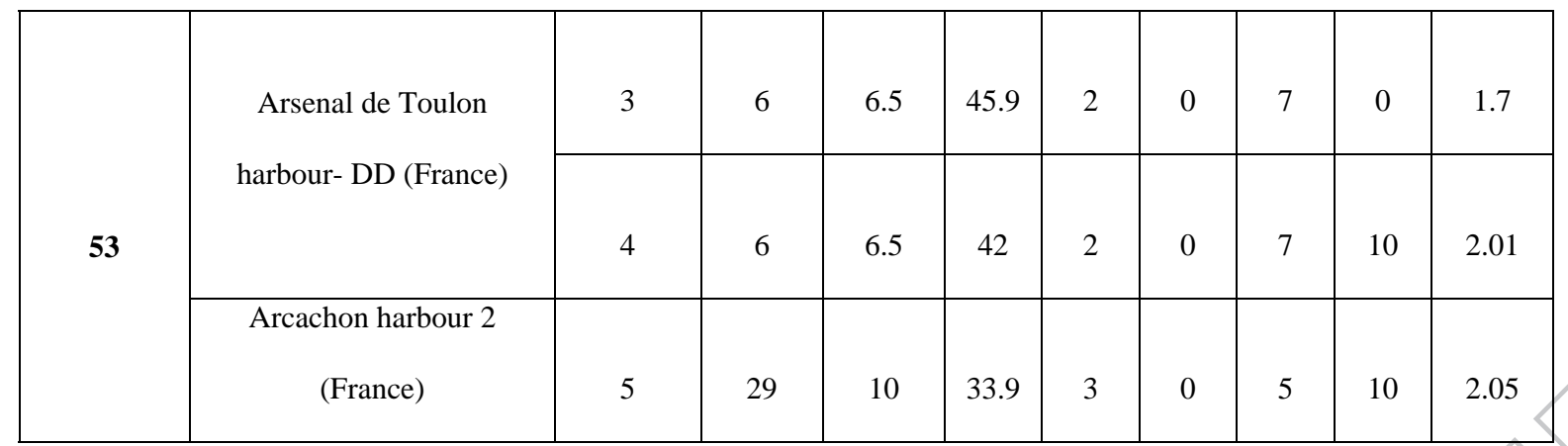

DD: Dehydrated-Desanded (Degritted)

Table 7. Evolution of UCS as function of time database

\begin{tabular}{|c|c|c|c|c|c|c|c|}
\hline $\operatorname{Mix} \mathbf{N}^{\circ}$ & $\mathbf{U C S}_{7}$ & $\mathrm{UCS}_{14}$ & $\mathrm{UCS}_{28}$ & $\mathrm{UCS}_{60}$ & $\mathrm{UCS}_{90}$ & $\mathrm{UCS}_{60} / \mathrm{UCS}_{28}$ & $\mathbf{U C S}_{90} / \mathrm{UCS}_{28}$ \\
\hline 20 & 0.42 & 0.52 & 0.78 & 0.77 & 0.79 & & 1.01 \\
\hline 21 & 0.5 & 0.59 & 0.73 & 0.84 & 0.87 & & 1.19 \\
\hline 22 & 0.65 & 0.82 & 0.98 & 1.05 & 1.06 & & 1.08 \\
\hline 23 & 0.76 & 0.9 & 1.16 & 1.19 & & 1.02 & 1.03 \\
\hline 24 & 0.8 & 0.95 & 1.2 & 1.26 & & 1.05 & 1.06 \\
\hline 25 & 0.87 & 1.08 & 1.29 & & 1.31 & 1.01 & 1.02 \\
\hline 26 & 0.89 & 1.2 & 1.32 & & 1.34 & 1.01 & 1.02 \\
\hline 27 & 0.95 & 1.29 & & 1.37 & 1.37 & 1 & 1 \\
\hline 28 & 1.01 & & 46 & 1.47 & 1.47 & 1.01 & 1.01 \\
\hline 29 & 1.07 & & & 1.58 & 1.6 & 1.01 & 1.02 \\
\hline 30 & & & 2.07 & 2.13 & 2.15 & 1.03 & 1.04 \\
\hline 31 & & 1.92 & 2.36 & 2.43 & 2.43 & 1.03 & 1.03 \\
\hline 32 & & 2.04 & 2.42 & 2.43 & 2.43 & 1 & 1 \\
\hline & & 2.13 & 2.49 & 2.55 & 2.53 & 1.02 & 1.02 \\
\hline & 2.06 & 2.32 & 2.55 & 2.55 & 2.57 & 1 & 1.01 \\
\hline 35 & 2.18 & 2.4 & 2.63 & 2.65 & 2.66 & 1.01 & 1.01 \\
\hline 36 & 2.42 & 2.66 & 2.95 & 2.99 & 2.99 & 1.01 & 1.01 \\
\hline 37 & 0.59 & 0.67 & 0.91 & 0.96 & 0.97 & 1.05 & 1.06 \\
\hline 38 & 0.54 & 0.62 & 0.86 & 0.85 & 0.86 & 0.99 & 1 \\
\hline 39 & 0.45 & 0.55 & 0.77 & 0.84 & 0.86 & 1.1 & 1.12 \\
\hline 40 & 0.44 & 0.89 & 1.25 & 1.26 & 1.27 & 1.01 & 1.01 \\
\hline 41 & 0.65 & 0.98 & 1.28 & 1.3 & 1.32 & 1.01 & 1.03 \\
\hline
\end{tabular}




\section{Annex}

\begin{tabular}{lccccccc}
\hline $\mathbf{4 2}$ & 0.7 & 1.03 & 1.4 & 1.49 & 1.5 & 1.06 & 1.07 \\
\hline $\mathbf{4 3}$ & 0.72 & 1.11 & 1.48 & 1.52 & 1.53 & 1.03 & 1.03 \\
\hline $\mathbf{4 4}$ & 0.9 & 1.19 & 1.5 & 1.52 & 1.53 & 1.02 & 1.02 \\
\hline $\mathbf{4 5}$ & 0.95 & 1.21 & 1.55 & 1.56 & 1.56 & 1 & 1
\end{tabular}

\begin{tabular}{|c|c|c|c|c|c|c|c|}
\hline $\operatorname{Mix} \mathbf{N}^{\circ}$ & $\mathbf{U C S}_{7}$ & $\mathrm{UCS}_{14}$ & $\mathbf{U C S}_{28}$ & $\mathbf{U C S}_{60}$ & $\mathrm{UCS}_{90}$ & $\mathrm{UCS}_{60} / \mathrm{UCS}_{28}$ & $\mathrm{UCS}_{90} / \mathbf{U C S}_{28}$ \\
\hline 46 & 1.07 & 1.28 & 1.58 & 1.61 & 1.63 & 1.02 & 1.03 \\
\hline 47 & 1.16 & 1.37 & 1.72 & 1.76 & 1.8 & 1.02 & 1.05 \\
\hline 48 & 1.14 & 1.56 & 2.12 & 2.14 & 2.17 & 1.01 & 1.03 \\
\hline 49 & 1.71 & 1.99 & 2.5 & 2.56 & 2.59 & 1.02 & 1.04 \\
\hline 50 & 1.96 & 2.21 & 2.67 & 2.7 & 2.71 & 1.01 & 1.02 \\
\hline 51 & 2.09 & 2.37 & 2.74 & 2.77 & 2.78 & 1.01 & \\
\hline 52 & 2.31 & 2.56 & 2.83 & 2.91 & 2.92 & 1.03 & \\
\hline 53 & 2.69 & 3.12 & 3.28 & 3.34 & 3.35 & & \\
\hline 54 & 3.24 & 3.57 & 4.12 & 4.15 & 4.15 & & 1.01 \\
\hline 55 & 1.33 & 1.63 & 1.9 & 1.94 & 1.94 & & 1.02 \\
\hline 56 & 1.12 & 1.57 & 1.84 & 1.92 & & 1.0 & 1.05 \\
\hline 57 & 0.92 & 1.36 & 1.61 & 1.62 & & 1.01 & 1.01 \\
\hline 58 & 0.61 & 1.21 & 1.51 & 1.59 & & 1.05 & 1.05 \\
\hline 59 & 0.6 & 1.18 & 1.46 & & 1.52 & 1.03 & 1.04 \\
\hline 60 & 0.53 & 0.98 & & & 1.31 & 1.05 & 1.11 \\
\hline 61 & 0.69 & 0.82 & & & 1.64 & 1.06 & 1.07 \\
\hline 62 & 0.62 & & & 1.52 & 1.58 & 0.99 & 1.03 \\
\hline 63 & 0.85 & & 1.83 & 1.9 & 1.92 & 1.04 & 1.05 \\
\hline 64 & & & 1.83 & 1.85 & 1.9 & 1.01 & 1.04 \\
\hline 65 & & & 1.68 & 1.89 & 1.91 & 1.13 & 1.13 \\
\hline 66 & 0.85 & 1.23 & 1.83 & 1.9 & 1.92 & 1.04 & 1.05 \\
\hline & 0.82 & 1.13 & 1.59 & 1.61 & 1.73 & 1.01 & 1.09 \\
\hline 68 & 0.75 & 1.19 & 1.78 & 1.83 & 1.7 & 1.03 & 0.96 \\
\hline 69 & 0.82 & 0.89 & 1.33 & 1.73 & 1.92 & 1.3 & 1.44 \\
\hline 70 & 0.7 & 0.87 & 1.33 & 1.93 & 1.83 & 1.46 & 1.38 \\
\hline 71 & 0.73 & 0.87 & 1.18 & 1.52 & 1.73 & 1.29 & 1.47 \\
\hline 72 & 0.67 & 0.81 & 1.19 & 1.52 & 1.63 & 1.28 & 1.37 \\
\hline
\end{tabular}




\section{Annex}

\begin{tabular}{|c|c|c|c|c|c|c|c|}
\hline 73 & 0.84 & 0.92 & 1.52 & 1.91 & 1.95 & 1.26 & 1.28 \\
\hline 74 & 0.73 & 0.88 & 1.42 & 1.7 & 1.73 & 1.2 & 1.22 \\
\hline 75 & 0.73 & 1.32 & 1.76 & 1.85 & 1.85 & 1.05 & 1.05 \\
\hline 76 & 0.77 & 1.4 & 1.83 & 2.02 & 2.02 & 1.11 & 1.11 \\
\hline 77 & 0.75 & 1.28 & 1.55 & 1.87 & 1.87 & 1.21 & 1.2 \\
\hline 78 & 0.86 & 1.67 & 1.91 & 2.02 & 2.03 & 1.06 & 1.06 \\
\hline 79 & 0.72 & 1.64 & 1.95 & 2.34 & 2.74 & 1.2 & 1.41 \\
\hline 80 & 1.03 & 1.72 & 2.2 & 2.49 & 3.1 & 1.13 & 1.41 \\
\hline 81 & 0.78 & 1.64 & 1.88 & 2.33 & 2.67 & 1.24 & 1.42 \\
\hline 82 & 0.89 & 1.7 & 1.97 & 2.51 & 2.81 & 1.28 & 1.43 \\
\hline 83 & 0.85 & 1.71 & 2.11 & 2.39 & 2.45 & 1.13 & \\
\hline 84 & 0.98 & 1.85 & 2.23 & 2.66 & 2.72 & 1.19 & \\
\hline 85 & 0.89 & 1.79 & 2.17 & 2.29 & 2.37 & & \\
\hline 86 & 0.82 & 1.93 & 2 & 2.48 & 2.5 & & 1.25 \\
\hline 87 & 0.9 & 1.38 & 1.72 & 1.89 & 1.91 & & 1.11 \\
\hline 88 & 0.92 & 1.48 & 1.97 & 2.09 & 2 & 1.06 & 1.08 \\
\hline 89 & 0.99 & 1.55 & 1.86 & 1.98 & & 1.06 & 1.08 \\
\hline 90 & 1.06 & 1.75 & 1.92 & 2.01 & 2.11 & 1.05 & 1.1 \\
\hline 91 & 0.9 & 1.48 & 1.71 & & 1.93 & 1.12 & 1.13 \\
\hline 92 & 0.9 & 1.42 & & & 2 & 1.08 & 1.1 \\
\hline 93 & 0.93 & 1.5 & & & 1.83 & 1.04 & 1.05 \\
\hline 94 & 0.88 & & & 1.86 & 1.89 & 1.01 & 1.03 \\
\hline 95 & 0.83 & & 1.36 & 1.84 & 1.91 & 1.35 & 1.4 \\
\hline 96 & 0 & & 1.4 & 1.81 & 1.86 & 1.29 & 1.33 \\
\hline 97 & & 1.0 & 1.39 & 1.59 & 1.59 & 1.14 & 1.14 \\
\hline 98 & 0.8 & 1.1 & 1.4 & 1.6 & 1.68 & 1.14 & 1.2 \\
\hline & 0.67 & 0.83 & 1.1 & 1.38 & 1.4 & 1.25 & 1.27 \\
\hline 100 & 0.7 & 0.87 & 1.04 & 1.4 & 1.46 & 1.35 & 1.4 \\
\hline 101 & 0.7 & 0.9 & 1.2 & 1.59 & 1.6 & 1.33 & 1.33 \\
\hline 102 & 0.76 & 0.97 & 1.28 & 1.52 & 1.58 & 1.19 & 1.23 \\
\hline 103 & 1.25 & 1.46 & 1.41 & 1.28 & 1.37 & 0.9 & 0.97 \\
\hline 104 & 1 & 1.22 & 1.25 & 1.15 & 1.21 & 0.93 & 0.97 \\
\hline
\end{tabular}




\section{Annex}

\begin{tabular}{llllllll}
\hline $\mathbf{1 0 5}$ & 0.87 & 0.93 & 0.97 & 0.81 & 0.87 & 0.83 & 0.89 \\
\hline $\mathbf{1 0 6}$ & 1.12 & 1.04 & 0.93 & 0.89 & 0.94 & 0.95 & 1.01
\end{tabular}

See Table 4 for sediment type, and applied treatment details according to Mix $\mathrm{N}^{\circ}$

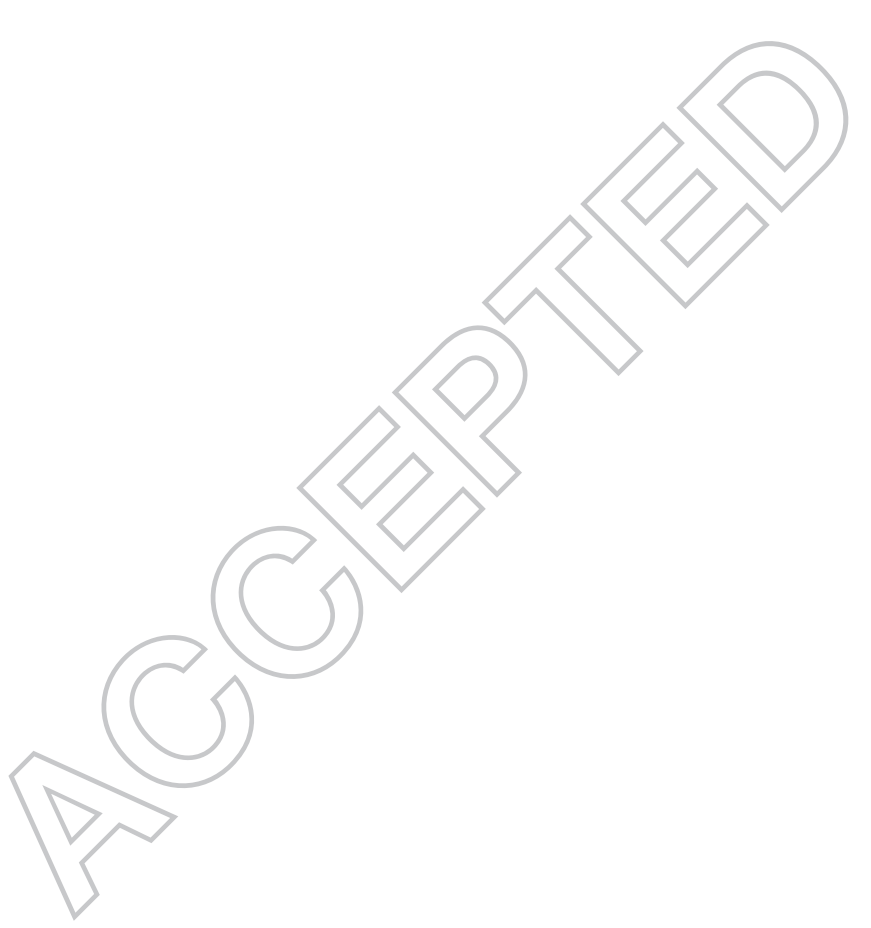

